Florida International University FIU Digital Commons

\title{
Conservation ecology of amphibians and reptiles in Sarapiqui, Costa Rica : forest fragmentation and long term population change
}

Kristen E. Bell

Florida International University

DOI: $10.25148 /$ etd.FI14050483

Follow this and additional works at: https://digitalcommons.fiu.edu/etd

Part of the Biology Commons

\section{Recommended Citation}

Bell, Kristen E., "Conservation ecology of amphibians and reptiles in Sarapiqui, Costa Rica : forest fragmentation and long term population change" (2005). FIU Electronic Theses and Dissertations. 1481.

https://digitalcommons.fiu.edu/etd/1481 


\section{FLORIDA INTERNATIONAL UNIVERSITY}

Miami, Florida

CONSERVATION ECOLOGY OF AMPHIBIANS AND REPTILES IN SARAPIQUÍ, COSTA RICA: FOREST FRAGMENTATION AND LONG-TERM POPULATION CHANGE

A thesis submitted in partial fulfillment of the requirements for the degree of MASTER OF SCIENCE in BIOLOGY by

Kristen E. Bell 
To: Interim Dean Mark Szuchman

College of Arts and Sciences

This thesis, written by Kristen E. Bell, and entitled Conservation Ecology of Amphibians and Reptiles in Sarapiquí, Costa Rica: Forest Fragmentation and Long-term Population Change, having been approved in respect to style and intellectual content, is referred to you for judgment.

We have read this thesis and recommend that it be approved.
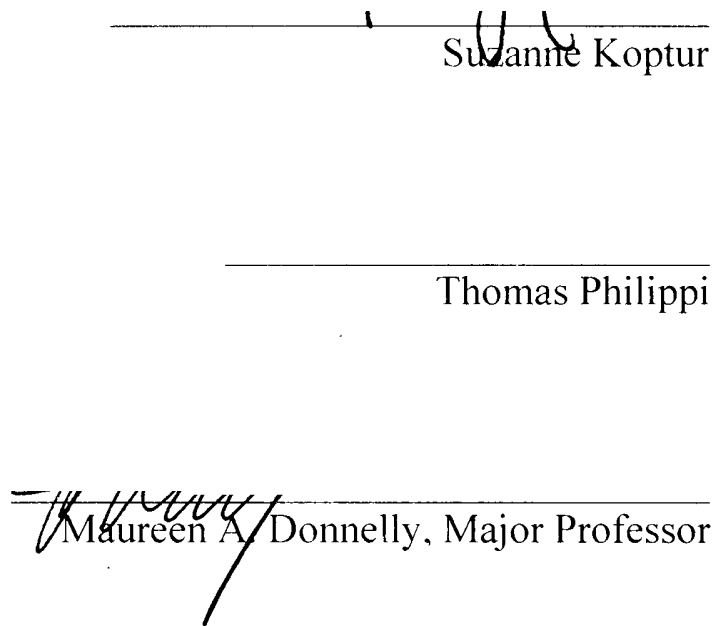

Date of Defense: June 24, 2005

The thesis of Kristen E. Bell is approved.

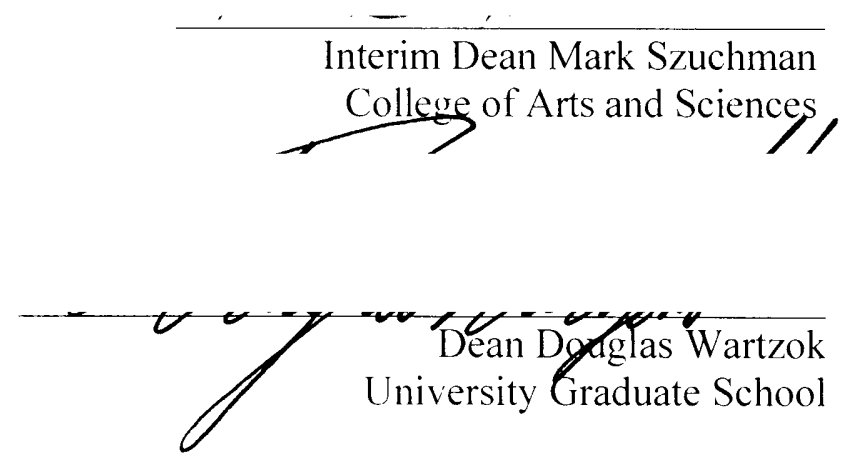

Florida International University, 2005 
(C) Copyright 2005 by Kristen E. Bell All rights reserved. 


\section{DEDICATION}

To my parents, for making all things possible. 


\section{ACKNOWLEDGMENTS}

I would like to offer my sincere gratitude to each of the following: The US EPA GRO Fellowship. Ted Stiles, Michael and Joan Bell, and the Organization for Tropical Studies for funding; Brian Shillinglaw, Apple Snider, Joan Bell, Matt de la Houssaye, Rachel Shuler, and Chuck Baker for field assistance; Steven Whitfield, Andres Vaughan, Mahmood Sasa, Branko Hilje, Craig Guyer, and Matt Williams for herp expertise; Antonio Trabucco and Marcía Snyder for GIS support; Catherine Woodward and Joe Meisel for their help in locating study sites; landowners in Sarapiquí for cooperation and access to their farms; Maureen Donnelly and Mahmood Sasa for use of their unpublished data, and all researchers at La Selva involved in herpetofaunal sampling over the past 35 years; the La Selva community; Maureen Donnelly, Suzanne Koptur, Tom Philippi, Craig Guyer, James Watling, Alessandro Catenazzi, Ralph Saporito, Steven Whitfield, Rudolf von May, Kia Ruiz, and David Kizirian for editorial comments; the lab for help and witty banter; Maureen Donnelly for guidance and support throughout; Steven Whitfield for being my greatest collaborator and friend; and Matt de la Houssaye for his faith in me and in the future. 


\begin{abstract}
OF THE THESIS
CONSERVATION ECOLOGY OF AMPHIBIANS AND REPTILES IN SARAPIQUÍ, COSTA RICA: FOREST FRAGMENTATION AND LONG-TERM POPULATION

CHANGE

by
\end{abstract}

Kristen E. Bell

Florida International University, 2005

Miami, Florida

Professor Maureen A. Donnelly, Major Professor

In order to explore the conservation ecology of frogs and lizards in the Sarapiquí region of Costa Rica, I compared populations and communities among forest fragments and La Selva Biological Station, as well as across 35 years of sampling at La Selva. Species richness in nine fragments combined was $85 \%$ of that found in La Selva, and community composition varied among sites and by fragment size class. Although communities in fragments differed fundamentally from those in intact forest, the high diversity observed across all fragments indicates that preserving a network of small forest patches may be of great conservation value to the herpetofauna of this region. According to data from past studies at La Selva, most common species of leaf-litter frogs and lizards demonstrated significant decreases in density over the 35 -year period. My findings may represent either natural population fluctuations or sweeping faunal declines at this site. 
I. INTRODUCTION 1

II. INFLUENCE OF FOREST FRAGMENTATION ON COMMUNITY STRUCTURE OF FROGS AND LIZARDS IN NORTHEASTERN COSTA RICA 3

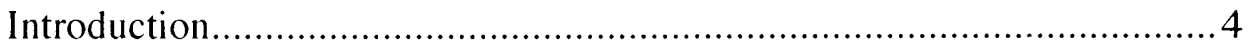

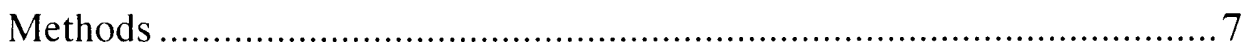

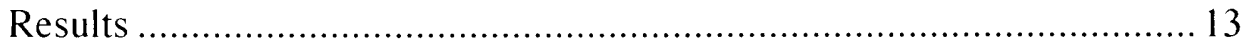

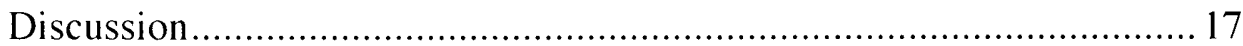

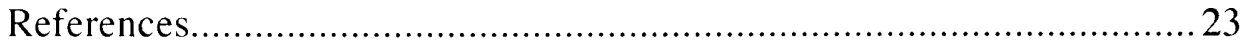

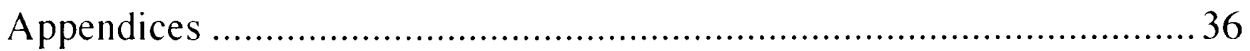

III. POPULATION VARIABILITY OF A LEAF-LITTER HERPETOFAUNA AT LA SELVA, COSTA RICA: SEASONAL AND LONG-TERM

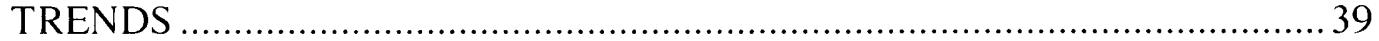

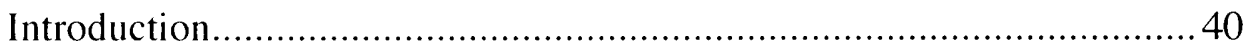

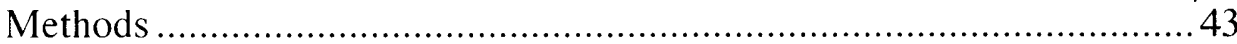

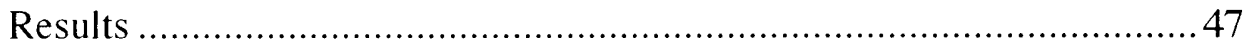

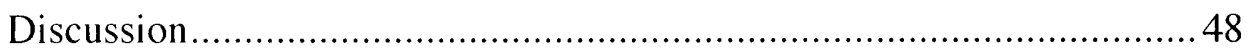

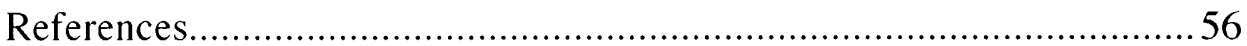

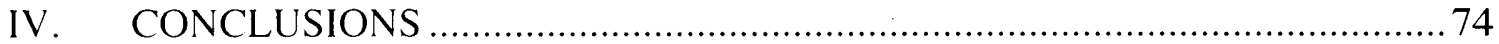




\section{LIST OF TABLES}

TABLE

PAGE

Table 1.1. Observed and estimated species richness across sites .................................35

Table 2.1. Inter-annual variation in population densities of tropical herpetofaunas.........69

Table 2.2. Seasonal variation in population densities of tropical herpetofaunas..............70

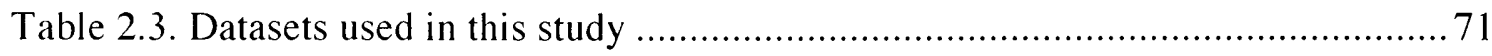

Table 2.4. Maximum seasonal change in abundance for two years.............................73

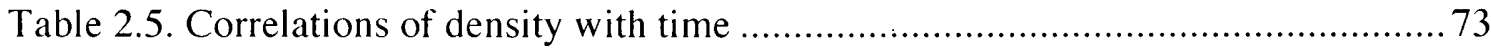




\section{LIST OF FIGURES}

FIGURE

PAGE

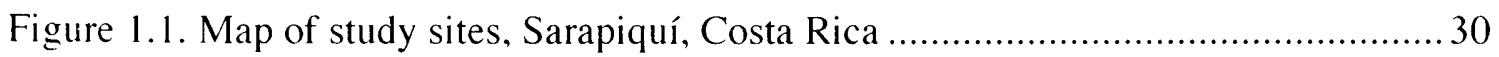

Figure 1.2. Size distribution of regional forest fragments.......................................... 31

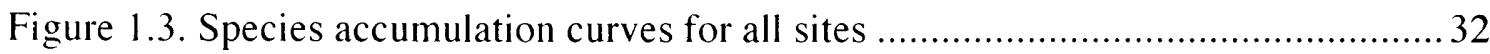

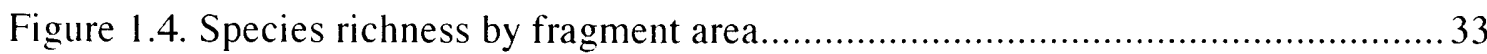

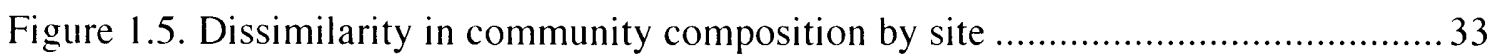

Figure 1.6. Density of frogs and lizards in fragments and La Selva ...............................34

Figure 1.7. Species occurrence in fragments by abundance at La Selva..........................34

Figure 2.1. Seasonal amphibian and reptile abundance, litter, and rainfall....................61

Figure 2.2. Seasonal changes in density for three common species .............................62

Figure 2.3. Density of species between 1970 and 2004 in primary forest .....................63

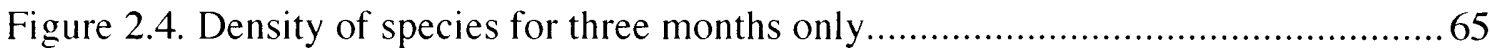

Figure 2.5. Density of species between 1970 and 2004 in cacao .................................66

Figure 2.6. Relative abundance of species in different years ...................................67

Figure 2.7. Temperature and rainfall data for the 35 -year period..................................68 


\section{INTRODUCTION}

Amphibian populations around the world have suffered declines and disappearances in the past few decades, threatened by a suite of factors including habitat loss and modification, disease, introduced species, acid precipitation, and climate change. Many of the same factors also threaten reptile populations, with the same negative consequences. The importance of these groups from an ecological perspective cannot be overstated; they make up the largest component of vertebrate biomass in many systems. and fill roles as primary, mid-level, and top consumers. The loss of reptiles and amphibians could have severe repercussions for communities and ecosystems; for effective conservation of these groups we need to understand the autecologies of amphibians and reptiles and how their populations respond to disturbance. In this project I focused on the population and community structure of frogs and lizards in the Sarapiquí region in the Caribbean lowlands of Costa Rica. I addressed two aspects of conservation ecology: responses to habitat fragmentation, and change across decades in an intact forest.

In the first chapter I report on community and population structure in nine small forest fragments, compared to intact forest at La Selva Biological Station. By systematically sampling in several forest fragments, I was able to compare species richness, community composition, and population densities among sites which varied in area. isolation, and habitat characteristics. Determining community structure in various fragment types can help inform conservation priorities, both by identifying potentially 
vulnerable species and by assessing the conservation value of small forest patches to amphibians and reptiles.

Chapter Two describes population change across 35 years at La Selva Biological Station, one of the most thoroughly studied sites in the neotropics. I compared population densities of leaf-litter reptiles and amphibians estimated from my sampling with those reported in comparable studies. Such long-term datasets from lowland tropical forest are extremely rare. Most reported amphibian declines from around the world occur primarily in montane sites, and the species affected tend to be aquaticbreeding species. Thus, although the data come from different sources and are therefore subject to various biases, this long-term population dataset for a lowland, terrestriallybreeding herpetofauna is especially useful for comparative purposes. 


\title{
Influence of forest fragmentation on community structure of frogs and lizards in northeastern Costa Rica
}

\author{
Kristen E. Bell
}

\section{Abstract}

I examined community and population structure of frogs and lizards in the fragmented landscape surrounding La Selva Biological Station in the Sarapiquí region of northeastern Costa Rica. Frogs and lizards were sampled in nine forest fragments (1-7 ha each) and La Selva (1100 ha) using diurnal quadrats and nocturnal transects; all sites were sampled monthly between October 2003 and August 2004. Species richness in all fragments combined was $82 \%$ of that found in La Selva with comparable sampling effort. Richness varied from 10 to 24 species among forest fragments, compared to 36 species at La Selva. Lizard density was higher and frog density lower in forest fragments than in continuous forest. Community composition varied among sites and by fragment size class, and species occurrence was nested with respect to fragment area. Isolation and habitat variables did not significantly affect species richness, composition, or nestedness. Between 18 and $25 \%$ of species I sampled in continuous forest were absent from forest patches. Such fragmentation-sensitive species may not survive outside continuous forest, while fragmentation-tolerant species remain abundant in forest fragments. Nevertheless, the high diversity observed in the entire set of fragments indicates that preserving a network of small forest patches may be of great conservation value to the amphibians and reptiles of this region. 


\section{Introduction}

Anthropogenic habitat destruction, modification, and fragmentation may represent the most serious threats to amphibians and reptiles worldwide (Corke 1992; Fisher and Shaffer 1996; Alford and Richards 1999). Although habitat fragmentation has been the focus of an extensive body of research (see Saunders et al. 1991; Andren 1994; McGarigal and Cushman 2002), relatively little is known of its effects on amphibians and reptiles, especially in tropical ecosystems (McGarigal and Cushman 2002). Neglecting these organisms is a serious oversight, considering their important roles in most ecosystems as primary, mid-level, and top consumers, sometimes comprising the largest component of vertebrate biomass in a system (Burton and Likens 1975; Reagan 1996). Negative effects of forest fragmentation may include declines in species diversity, decreased abundance, changes in species composition, changes in demographic parameters, and decreased genetic diversity (Saunders et al. 1991; Turner 1996; Laurance et al. 2002). The type and severity of community responses to fragmentation depend on a suite of factors that can be grouped into three categories: area effects, edge effects, and position in the landscape (Saunders et al. 1991; Fahrig and Merriam 1994).

As fragments decrease in area, they are predicted to contain fewer species (Connor and McCoy 1979) and smaller populations (Bender et al. 1998), which are prone to extirpation because of stochastic change (Shaffer 1981). Abiotic conditions at the forest edge, such as increased wind and solar radiation, increased fluctuations in temperature, and decreased humidity, may functionally reduce the size of a fragment for forest-adapted organisms (Saunders et al. 1991; Murcia 1995). Edges can also affect entire fragments by making them more susceptible to agrichemical inputs, selective 
logging, livestock grazing, or fire (Turner 1996). Forest structure and dynamics are altered in fragments (Murcia 1995; Laurance et al. 2002), which can result in higherorder effects (e.g., changes in community structure and ecosystem processes; Turner 1996; Laurance et al. 1997). At the landscape scale, the distance separating habitat patches affects the movement of organisms between them (Brown and Kodric-Brown 1977). The presence of habitat corridors and the type of matrix surrounding a fragment also influence dispersal rates of organisms (Fahrig and Merriam 1994; Gascon et al. 1999; Lima and Gascon 1999). Finally, all of the above effects change with increasing time since a fragment's isolation (Gonzalez 2000; Grez et al. 2004).

Species vary in their tolerances of forest fragmentation. Characteristics that contribute to fragmentation sensitivity include low abundance, large area requirement, high population fluctuation, low fecundity, low dispersal ability, and specialized habitat requirements (Henle et al. 2004). Predictions based on these qualities are difficult to make in the absence of detailed autecological information, as is often the case for tropical organisms. As a group, amphibians may be especially vulnerable to fragmentation because their relatively narrow moisture and temperature tolerances (Duellman and Trueb 1986) and specific breeding habitat requirements (Zimmerman and Bierregaard 1986) may restrict the types of habitat they can occupy and limit movement between them. Several studies have documented negative responses of tropical amphibians to habitat fragmentation, including decreased diversity (Vallan 2000; Pineda and Hallfter 2004), decreased abundance (Marsh and Pearman 1997), edge avoidance (Schlaepfer and Gavin 2001; Lehtinen et al. 2003), reduced fecundity (Funk and Mills 2003), and changes in community composition (Gascon et al. 1999; Pineda and Hallfter 2004). 
In general, reptiles are not as constrained by moisture requirements as amphibians, and lizards may be unaffected by fragmentation (Jellinek et al. 2004) or occur at higher densities along fragment edges (Schlaepfer and Gavin 2001; Lehtinen et al. 2003). Nonetheless, many reptile species and communities are sensitive to fragmentation (Sarre et al. 1995; Cosson et al. 1999; MacNally and Brown 2001; Driscoll 2004). Conversely, both amphibians and reptiles may be less severely affected by fragmentation than birds and mammals (Dickman 1987; Smith et al. 1996; Gascon et al. 1999), in some cases even increasing in species richness with fragmentation (Tocher et al. 1997). Compared to similar-sized homoiotherms, reptiles and amphibians have lower energetic requirements, smaller home ranges, and higher densities (Pough 1980), which could allow the maintenance of viable populations in small patches (McGarigal and Cushman 2002).

We need to more fully understand the responses of tropical herpetofaunas to rapid land-use change. Tropical forests continue to be logged and destroyed at a rate of about 16 million ha per year (Laurance 1999). Our current understanding of amphibians' responses to fragmentation in Neotropical lowland rain forest is based almost entirely on data from experimentally isolated fragments at one Amazonian site near Manaus, Brazil (Tocher et al. 1997). Increased knowledge of how organisms use forest fragments can add to our understanding of the impacts of land use change in the tropics, as well as help inform local conservation efforts (Matlock et al. 2002; Luck and Daily 2003). Effective conservation strategies must operate at the landscape level and include enough sites to maintain high diversity and natural communities (Margules et al. 1988). In order to select an appropriate network of patches to protect, we must first describe the distribution 
of species and communities (Saunders et al. 1991), and then determine which factors have the greatest influence on diversity and species composition within forest fragments.

Often, the well-studied intact ecosystems inside parks and preserves are not contextualized within the surrounding anthropogenic landscape. La Selva Biological Station is one of the most extensively studied forests in the Neotropics (Clark 1990); however, the surrounding Sarapiquí region has been converted from continuous lowland wet forest to an agriculture-dominated landscape over the past 40 years (Butterfield 1994). These circumstances make it increasingly necessary to relate research done in La Selva's primary forest to the highly fragmented surrounding landscape (see Guariguata et al. 2002; Matlock et al. 2002). My study examines patterns in the abundance and distribution of lizards and frogs in the fragmented landscape surrounding La Selva Biological Station in Costa Rica. This study has two main objectives: (1) to describe the community structure of frogs and lizards across fragments of different areas and isolations versus a reference area in continuous forest, and (2) to compare estimates of density and age structure of populations between fragmented and continuous forest.

\section{Methods}

\section{$\underline{\text { Study Sites }}$}

Research was conducted in and around La Selva Biological Station in the Caribbean lowlands of Costa Rica. La Selva is located in Sarapiquí canton in the province of Heredia, at the confluence of the Puerto Viejo and Sarapiquí rivers ( $10^{\circ} 26^{\prime}$ $\mathrm{N}, 83^{\circ} 59^{\circ} \mathrm{W}$ ); for a complete description of the site, see McDade and Hartshorn (1994). It has a diverse and relatively well-known herpetofauna, with 25 lizard and 46 frog 
species recorded from the site (Donnelly 1994; Guyer 1994; Savage 2002; Guyer and Donnelly 2005). About 70\% of La Selva's 1600 ha is primary forest, and it adjoins the 45,000-ha Braulio Carrillo National Park. In the 1950s, the Sarapiquí region was almost entirely covered by lowland tropical wet forest. Escalating conversion of lands to agricultural uses has resulted in a large reduction of forested area, which decreased from about 70\% in 1963 (Butterfield 1994) to 55\% in 1976 and 34\% in 1996 (SánchezAzofeifa et al. 1999). Between 1976 and 1996, the number of forest fragments more than doubled and average fragment size decreased (Sánchez-Azofeifa et al. 1999). Principle land-use categories in the region are now secondary forest, pasture, and banana plantation.

I selected nine fragments that ranged in area from one to seven hectares, isolated from other forest and located varying distances from the nearest forest (Fig. 1.1, Appendix 1). The primary and selectively logged portions of La Selva (about 1100 ha within the 1600-ha preserve, which is contiguous with a large national park) served as a reference area of continuous forest. Small fragments were chosen for biological and geographical reasons. Frogs and lizards, with their small body sizes and modest home range requirements, may be able to maintain viable population sizes in small forest patches. Also, small fragments are typical of forest fragments in the region. I analyzed a 177- $\mathrm{km}^{2}$ area around La Selva using $2.5 \mathrm{~m}$-resolution satellite Quickbird images from 2003 (within the dotted line, Fig. 1.1). After on-screen digitizing of all forest patches, I found that $80 \%$ of forest fragments were less than 10 ha in size, with a median size (excluding protected areas) of 2.6 ha (Fig. 1.2). This was also the median size of my study sites. Of regional forest fragments, $55 \%$ fell within the size range of my study sites 
(1-8 ha). I chose fragments that were mostly or entirely surrounded by pasture in order to minimize the effects of matrix composition on fragment communities; however, there was considerable variation among pastures in terms of topography, wetlands, shade, and grazing intensity. The length of time each fragment had been isolated from other forest, estimated from landowner interviews and aerial photos, ranged from 17 to 34 years, with a mean of 26 years. The fragments also varied in forest structure, and all were moderately to heavily impacted by humans. Although this variation may confound my results, it is typical of forest in the region. Forest use commonly includes selective logging, understory clearing, and cattle grazing; no undisturbed forest remains outside protected areas.

Sampling methods

I used two standard sampling methods to assess species composition and abundance at each site: diurnal leaf-litter quadrat samples (Jaeger and Inger 1994) and nocturnal visual encounter surveys (VES) along transects (Crump and Scott 1994). The nocturnal VES method is one of the most effective for sampling tropical herpetofaunas, generally yielding greater numbers of individuals and species per unit effort than other sampling methods (Pearman et al. 1995; Doan 2003; Donnelly et al. 2005). Leaf litter quadrat sampling, while detecting fewer species, provides fairly accurate estimates of density and is useful for comparisons among studies and sites (Allmon 1991); this method has been used previously at La Selva to assess the litter herpetofauna (Scott 1976; Fauth et al. 1989; Heinen 1992; Watling and Donnelly 2002; Watling et al. in press). Species in this assemblage have been shown to differ in diel activity patterns and vertical habitat use (Miyamoto 1982; Slowinski et al. 1987). By combining the two methods I 
was able to describe a wider assemblage than I could using a single method (Doan 2003; Donnelly et al. 2005), including both the leaf-litter community and many arboreal, semiarboreal, and semiaquatic species.

Each quadrat and transect was randomly placed and sampled only once. Leaf litter quadrats were $5 \times 5 \mathrm{~m}$; they were searched by two people, who raked aside and thoroughly searched under all leaf litter and cover objects. Litter plots took an average of 19 minutes (+/- 6 min SD) to search. The VES belt transects were $50 \times 4 \mathrm{~m}$. Transects were established with a 50-m string; two observers walked slowly, one on either side of the string, each visually searching the entire 4-m width of the transect. Each transect took an average of 30 minutes $(+/-7 \mathrm{~min} S \mathrm{~S})$ to complete.

Quadrats and transects were placed in fragments using the following method. A random compass direction overlaid on a map of the fragment decided the initial point of entry into the fragment. From this starting point at the edge, a randomly-chosen compass direction and number of steps were taken (100 steps in small fragments, 200 in medium fragments), followed by a second random direction and number of steps. If an edge was encountered (defined as the last line of tree trunks), a 90-degree turn was made in order to stay within the fragment. The quadrat or transect was located at the end point of this random walk. Transects were oriented according to an additional random direction. This method oversamples edge relative to core habitat in fragments, but is otherwise a practical approximation of random sampling. In La Selva, sampling locations were picked using the GIS grid system. A computer program selected random grid poles in primary and selectively logged forest within $150 \mathrm{~m}$ of a trail. Quadrats were placed at the 
grid poles; transects extended from the pole away from the nearest trail, to minimize effects of human disturbance.

Sampling effort was greater at larger sites to control for differences in area (Schoereder et al. 2004). Fragments were classified as small (1.4-2.6 ha) or medium (46.9 ha). Each month, four quadrats and three transects were searched in each small site, six quadrats and six transects in each medium site, and 15 quadrats and 15 transects in La Selva. Generally, quadrats were searched during morning hours and transects were established following plot sampling. Transects were sampled after dark, between 1800 and 2300 hours. Quadrat sampling ran from October 2003 through April 2004. Transect sampling continued from October 2003 through July 2004, with full datasets completed for every month but October 2003 (preliminary data) and May 2004 (heavy flooding). Data collection and analysis

All amphibians and reptiles encountered were captured, identified to species, measured (snout-vent length), and released. For each fragment, the area, distance to nearest large ( $>300 \mathrm{ha}$ ) forest, and area of forest within $1 \mathrm{~km}$ of the fragment were measured using GIS analysis of Landsat and Quickbird images. I measured stream length to calculate the ratio of stream length to area for each fragment. Understory plant density was quantified by using a Secchi disk ( $25 \mathrm{~cm}$ diameter): one person held the disk vertically at a height of $50 \mathrm{~cm}$ while the other walked away, measuring the distance at which the disk was no longer visible $(\mathrm{N}=340)$. To approximate leaf litter depth, a $30 \mathrm{X}$ $30 \mathrm{~cm}$ sample of litter was collected from one corner of each quadrat, dried at $70^{\circ} \mathrm{C}$ for 48 hours, and weighed $(\mathrm{N}=344)$. Canopy cover was measured at each quadrat by taking the mean of four spherical densiometer readings $(\mathrm{N}=393)$. Size of the largest trees was 
quantified by taking the mean DBH of the three largest trees within $10 \mathrm{~m}$ of the center of each quadrat $(\mathrm{N}=399)$.

I assessed sampling completeness with respect to species richness by calculating incidence-based and abundance-based estimators (ICE, ACE) and constructing species accumulation curves (both by sampling effort and by number of individuals) with the program EstimateS (Colwell 2004). Species richness, evenness, and population density were compared among fragments using nonparametric Spearman`s rank correlations because of the small sample size $(n=9)$. Understory density, litter depth, and DBH were log-transformed; canopy cover was arcsine square-root transformed. Variances were unequal even after transformations, so habitat variables for all fragments combined and La Selva were compared using a Wilcoxon rank-sum test. In order to test for differences in community composition by site, I used a nested analysis of similarity (ANOSIM), with each transect as a sample, abundance of each species as dependent variables, and site nested within forest type (fragmented/continuous) as factors. I also evaluated community similarity with site nested within size class Ismall (1-4 ha), medium (5-7 ha), and La Selva (continuous)|. Each ANOSIM was based on a Bray-Curtis dissimilarity matrix. using PRIMER 5.0 (Clarke and Warwick 2001). To determine which combination of habitat variables most influenced community composition, I performed the BIO-ENV procedure, which correlates Bray-Curtis dissimilarity matrices of community composition with Euclidean distance dissimilarity matrices of habitat variables. I used BIO-ENV for 10 sites (including La Selva) with the following variables: canopy, litter, DBH, and understory; and in nine sites (fragments only) with: canopy, litter, DBH, understory, area, isolation, distance, streams, and age. I looked for nested patterns of 
species occurrence using the Nested Temperature Calculator (Atmar and Patterson 1995).

Densities of frogs and lizards were compared for all fragments combined versus La Selva using a Wilcoxon rank-sum test (due to unequal variances) with transect or quadrat as the sampling unit. Proportions of juveniles for 11 abundant species were compared among sites with chi-square tests and compared between fragments and La Selva with Z-tests.

\section{Results}

Sampling completeness

I encountered an estimated $74-96 \%$ of the frog and lizard species at each site (using the abundance-based estimator ACE in EstimateS; Colwell 2004). Species accumulation curves plotted by transect and by number of individuals yielded similar patterns, indicating that the differences in number of sightings per transect did not affect the sampling curve. La Selva had the steepest accumulation curve, followed by the two largest fragments (Fig. 1.3a). When correlated with area, the estimated richness values of ACE and ICE yielded similar results to my observed species richness (Table 1.1); therefore, I used observed values for subsequent analyses.

\section{$\underline{\text { Species richness and evenness }}$}

During the ten-month study, I found 36 anuran and 14 lizard species across all sites using the two sampling methods. Richness of fragments ranged from 10 to 24 species. Thirty-six frog and lizard species were encountered at La Selva. Species richness of all fragments combined exceeded the number of species I recorded at La Selva, totaling 41 species; however, this is probably the result of greater sampling effort across all fragments (350 transects, vs. 132 transects in la Selva). When species 
accumulation for all fragments combined was stopped at the same number of individuals as La Selva, richness was $85 \%$ of that found at La Selva (Fig. 1.3b). Among fragments, total species richness was positively correlated with fragment area (Spearman; $\mathrm{n}=9, r_{s}=$ $0.67, P=0.049$; Fig. 1.4), although this was primarily an effect of high richness in the largest two sites. The same trend was present for frogs $\left(r_{\mathrm{s}}=0.41, P=0.055\right)$ and lizards (excluding one outlier site; $r_{s}=0.82, P=0.012$ ) when analyzed separately. Evenness was similar across sites $\left(r_{s}=0.03, P=0.93\right)$. There was no relationship between species richness and fragment isolation, according to the two measures employed: distance from nearest large forest and area of forested land within $1 \mathrm{~km}$ of the fragment.

\section{Forest structure}

Proportion of edge habitat increased with decreasing fragment size $\left(r^{2}=0.69, P=\right.$ 0.006). Tree size $(\mathrm{DBH})$ did not vary between continuous and fragmented forest $\left(\chi^{2}=\right.$ $0.34, P=0.56)$. Litter depth was greater in fragments than in continuous forest $\left(\chi^{2}=\right.$ 7.74, $P=0.005)$. Canopy cover was less $\left(\chi^{2}=6.08, P=0.014\right)$ and the understory more dense $\left(\chi^{2}=7.98, P=0.005\right)$ in forest fragments than in continuous forest. None of these variables was correlated with fragment area.

\section{Community composition}

Relative abundance of species varied among sites. Norops limifrons was the most abundant species at four sites; Dendrobates pumilio was the dominant species at three sites; and Eleutherodactylus ridens and E. fitzingeri were each dominant at a single site. The most abundant species in each fragment accounted for 18 to $45 \%$ of all observations at that site (Appendix 2). 
Nonmetric multidimensional scaling (nMDS) plots of similarity in community composition showed apparent clustering of sites according to their size (Fig. 1.5). There were significant differences in community composition among sites (Global $R=0.25, P$ $=0.01$ ) as well as among fragment size classes (Global $R=0.44, P=0.026)$ in a nested

ANOSIM. However, none of the pairwise comparisons was significant. The significant differences in community composition among sites (Global $R=0.26, P=0.01$ ) outweighed differences between fragmented and continuous forest (Global $R=0.51, P=$ 0.10 ) in a nested ANOSIM. According to BIO-ENV analyses, no habitat variable or group of variables was strongly correlated with community composition among sites; correlation coefficients did not exceed 0.32 in any analysis.

Species occurrence was significantly nested among fragments. This was true for frogs $(\mathrm{T}=17.31, P<0.001)$, lizards $(\mathrm{T}=19.84, P=0.003)$, and both $(\mathrm{T}=24.04, P<$ 0.001) when the analysis included La Selva. When only fragments were compared, the nested pattern was weaker for each group (frogs: $\mathrm{T}=23.87, P<0.001$; lizards: $\mathrm{T}=$ $27.63, P=0.045$; and both: $\mathrm{T}=32.86, P=0.001)$. Nested rank of fragments was significantly correlated with fragment area $\left(r_{,}=-0.75, P=0.02\right)$ but not with distance $\left(r_{\text {s }}\right.$ $=0.07, P=0.86)$, isolation $\left(r_{\mathrm{s}}=-0.42, P=0.26\right)$, or any habitat variable.

\section{Population structure}

Densities were calculated using day (402 total quadrats) and night (482 total transects) data separately (Fig. 1.6). Anuran density was higher in continuous than fragmented forest for day sampling (Wilcoxon; $\chi^{2}=7.20, P=0.007$ ). For night sampling, however, there was no difference in anuran density between continuous and fragmented forest $\left(\chi^{2}=1.52, P=0.22\right)$. Lizard density was higher in fragmented than 
continuous forest for both day $\left(\chi^{2}=8.33, P=0.004\right)$ and night $\left(\chi^{2}=20.61, P<0.001\right)$ sampling. There were no correlations between fragment area and total density of frogs, lizards, or most of the abundant species, with the following exceptions: there were positive correlations between fragment area and density for centrolenids $\left(r_{s}=0.74, P=\right.$ $0.022)$ and two Eleutherodactylus, E. ridens $\left(r_{s}=0.72, P=0.029\right)$ and E. noblei $\left(r_{s}=\right.$ $0.82, P=0.007$ ) from night sampling data.

Mean proportion of juveniles across sites was 0.41 for lizards $(+/-0.10 \mathrm{SD})$ and 0.32 for frogs (+/-0.09 SD). Only three of the 11 species analyzed showed significant variation in the proportion of juveniles among fragments, and these did not vary according to fragment area, isolation, or habitat variables. Proportions of juveniles for most abundant species did not differ between continuous and fragmented forest, with the exception of two species, Eleutherodactylus fitzingeri $(Z=2.07, P=0.025)$ and Norops limifrons $(Z=2.27, P=0.005)$, which had higher proportions of juveniles in fragments.

\section{Fragmentation-sensitive species}

Since the entire region was once forested, it may be reasonable to use the abundance of species at La Selva as an estimate of natural commonness/rarity for the region (Vallan 2000). Frequency of occurrence in fragments was plotted according to (log-transformed) abundance at La Selva for each species. I used confidence intervals from the resulting linear relationship to separate species which closely follow the expected pattern from fragmentation-tolerant species (those that occur more frequently in fragments than predicted by their abundance at La Selva) and fragmentation-sensitive species (those that occur in fewer fragments than predicted by their La Selva abundance; Fig. 1.7). 


\section{Discussion}

Observed species richness ranged from 10 to 24 species for each fragment, and pooled richness of all fragments was 29 at a sampling effort comparable to that accomplished at La Selva. According to my sampling, nine small fragments may preserve about $85 \%$ of the species found in primary, continuous forest in this region. However, these results should be interpreted with caution, because species richness observed 17-34 years post-isolation may still be decreasing as small populations are extirpated. Additionally, this 10-month study did not detect all the region's species. Seventy-one frog and lizard species have been recorded from La Selva; I encountered 36 species at La Selva and 50 species across all sites.

I found a significant species-area relationship among fragments (Fig. 1.4, Table 1.1), although this was primarily the result of high richness in the largest two fragments. This may indicate the presence of a "small island effect," a threshold in area (in this case around 5 ha) below which there is no species-area relationship due to variation in island characteristics (Lomolino and Weiser 2001). Although the forest fragments in this study varied in terms of forest structure, leaf litter depth, and stream density, area was the best predictor of richness. Isolation, on the other hand, did not affect species richness. In general, area seems to be a better predictor of richness in forest fragments than isolation (e.g., Bolger et al. 1997; Pineda and Hallfter 2004), although this could reflect the recent isolation of most fragments, which have not had time for extinction/colonization dynamics to shape communities (Gonzalez 2000).

I found greater leaf-litter depth, less canopy cover, and a denser understory in fragmented than in continuous forest. These characteristics were not correlated with 
fragment size. Among fragments, habitat differences that were not quantified included topography, presence and type of wetlands, and human disturbance. All fragments had been previously logged to some extent, which affected forest structure. The most obvious source of ongoing disturbance in the fragments was livestock; cattle churned up mud, compacted soil, and opened the understory.

Community composition was not correlated with habitat variables or measures of isolation in multivariate analyses, but composition did vary by fragment size class (Fig. 1.5). Species occurrence demonstrated a significantly nested pattern, both among fragments and including La Selva; this was true for both frogs and lizards, although for lizards the relationship was weak among fragments. The assemblage was nested with respect to fragment area, but not isolation or habitat variables. The nonrandom distribution of species across sites implies the existence of a set of species that are systematically lost from smaller patches. Area is the only site characteristic correlated with species richness, community composition, and nestedness. Clearly, the area of a forest patch has some influence on its community structure. However, the great variation observed among sites in terms of both diversity and composition points to the ubiquity of unpredictable and random change in small populations.

Two species and one family of frogs showed significant increases in density with fragment area. Similar patterns have been found for some lizards (Hokit and Branch 2003), frogs (Marsh and Pearman 1997), birds, and mammals (Bender et al. 1998). For the large majority of species I encountered, however, density was not correlated with area. Overall, anuran density was lower in fragmented than continuous forest, while lizard density was higher. This could be due to physiological constraints or preferences 
specific to the two groups. Anuran activity patterns may be based on moisture availability; frogs were less dense in fragmented forest during the day, but of equal density compared to continuous forest at night, when humidity tends to be higher. Some tropical lizards have higher densities (Schlaepfer and Gavin 2001; Lehtinen et al. 2003) or faster incubation times (Schlaepfer 2003) in edge or open habitat.

For most of the abundant frog and lizard species, proportions of juveniles did not differ between continuous and fragmented forest and remained remarkably similar across sites. The two species displaying greater proportions of juveniles in fragments ( $E$. fitsingeri and $N$. limifrons) are characteristic of disturbed and edge habitat (Savage 2002). According to this rough estimate of recruitment, successful reproduction occurs in fragments as well as continuous forest; however, more detailed study of reproduction in fragments is clearly needed. Fragmentation has been demonstrated to reduce clutch size in one anuran species in Brazil (Funk and Mills 2003). Many anurans have specific breeding habitat requirements; for these species, presence or absence of breeding habitat may be the single most important factor determining persistence at a site (Zimmerman and Bierregaard 1986). For instance, I found Rana vaillanti only in sites with slowflowing streams or ponds and Hyla ebraccata only in sites with grassy temporary ponds. Breeding habitat cannot, however, explain the distribution of dendrobatids and most leptodactylids, which reproduce terrestrially, because leaf-litter depth was not correlated with abundance or proportion of juveniles of these groups.

My study did not attempt to investigate movement or migration of herpetofauna across the landscape, although this is an important consideration for any fragmented landscape. The ability of an organism to use (or disperse through) matrix habitat has 
been negatively correlated with sensitivity to fragmentation (Gascon et al. 1999). Unshaded pasture can be a hostile environment to small ectotherms, because of desiccation and predation risks (Rothermel and Semlitsch 2002). At a montane site in Ecuador, only $6 \%$ of total frog abundance occurred in pasture vs. forest, and $3 \%$ in cropland vs. forest (Toral et al. 2002). In contrast, $65 \%$ of forest frog species were encountered in pasture in lowland Brazil (Gascon et al. 1999). Even with such considerable barriers to movement, moderate-range movement of small reptiles and amphibians is probably common. For instance. I found an adult Agalychnis callidryas, a temporary pond breeder, in a fragment with no standing or flowing water; this species is known to move up to $300 \mathrm{~m}$ in a single night, and is often found breeding in pasture ponds (M. Williams, personal communication). Similarly, Hyalinobatrarhium pulveratum, a stream-breeding centrolenid, was found in a fragment with no flowing water, implying an ability to move through pasture. Although I tried to choose fragments that were completely surrounded by pasture, several had narrow forested streamside corridors connecting them to other forest patches. Such corridors are common in the region, and their contribution to landscape connectivity invites further study.

Plotting species' abundance at La Selva by their occurrence in fragments (Fig. 1.7), I identified a group of 16 fragmentation-tolerant species (Eleutherodactylus bransfordii, E. fitzingeri, E. diastema, E. ridens, Scinax eleaochroa, S. boulengeri, Smilisca puma, Agalychnis callidryas, Rana vaillanti, Corytophanes cristatus, Norops limifrons, N. humilis, N. carpenteri, Ameiva festiva, Lepidoblepharis xanthostigma, and Sphenomorphus (herriei) and a group of 17 fragmentation-sensitive species (Eleutherodactylus talamancae, E. cerasinus, E. crassidigitus, E. cruentus, E. 
megacephalus, E. mimus, Agalychnis saltator, A. calcarifer, Hyla rufitela, H. ebraccata, Smilisca sordida, Centrolenella prosoblepon, Gastrophryne pictiventris, Bufo melanochlorus, Rana warszewitschii, Norops lemurinus, and N. capito). This second group includes several species that seem to be rare in general, and I do not want to confuse overall rarity in the landscape with fragmentation-sensitivity per se.

Nevertheless, descriptions of habitat preference for these species, when available, largely agree with my designations (Savage 2002; Guyer and Donnelly 2005).

Based on my sampling, $18 \%$ of total species were absent from fragmented forest, and $28 \%$ of total species were absent from La Selva. However, all species absent from La Selva had been recorded there previously. Additionally, 27 species previously recorded from La Selva were not sighted during my study; these either naturally occur at low abundances, have patchy distributions, occur mainly at higher elevations or in the canopy, or may have declined at this site. Many of these species could prove even more sensitive to fragmentation than the species recorded during my study.

I found that many species described as preferring primary forest (Savage 2002) were present or even abundant in small forest fragments. These species may be wrongly characterized due to a paucity of research conducted in secondary and disturbed forest in the region. Although many forest species did well in fragments, there did not appear to be a non-forest, disturbance-adapted guild invading fragments. Species such as Bufo marinus, Gonatodes albogularis, and Hemidactylus frenatus are common around human habitations in this area but were not recorded in forest fragments. 


\section{Conclusions}

The small forest fragments I studied each contained 20 to $50 \%$ of the anuran and lizard species found in the region, a greater number of species than might be expected based on the small sizes and high levels of disturbance of the study sites. The relatively high diversity I observed in these sites makes them relevant in terms of reptile and amphibian conservation, although fragments may still be losing species decades after isolation. Taken together, my nine fragments contained $82 \%$ of the species richness encountered in continuous forest (58\% of the regional total). Preserving a network of small forest patches may be of great conservation value to herpetofauna in the Sarapiquí region and at other lowland sites. Unfortunately, at this time landowners have little incentive to preserve forest, especially small $(<10 \mathrm{ha})$ patches of forest.

Although a significant proportion of the herpetofauna may be able to exist in small forest patches, it should be recognized that the communities in these fragments are fundamentally different from the intact forest community. Nine of the 36 species (25\%) I found in continuous forest were missing from fragments. Species composition and relative abundances differ, and fragments tend to support higher densities of lizards and lower densities of frogs than continuous forest. Therefore, the continued presence of La Selva and other large reserves is vital to the preservation of reptiles and amphibians in the fragmented Sarapiquí region. 


\section{References}

Alford, R. A., and S. J. Richards. 1999. Global amphibian declines: a problem in applied ecology. Annual Review of Ecology and Systematics 30:133-165.

Allmon, W. D. 1991. A plot study of forest floor litter frogs, Central Amazon, Brazil. Journal of Tropical Ecology 7:503-522.

Andren, H. 1994. Effects of habitat fragmentation on birds and mammals in landscapes with different proportions of suitable habitat: a review. Oikos 71:355-366.

Atmar, W., and B. D. Patterson. 1995. The nested temperature calculator: a visual basic program, including 294 presence-absence matrices. AICS Research Incorporated and The Field Museum.

Bender, D. J., T. A. Contreras, and L. Fahrig. 1998. Habitat loss and population decline: a meta-analysis of the patch size effect. Ecology 79:517-533.

Bolger, D. T., A. C. Alberts, R. M. Sauvajot, P. Potenza, C. McCalvin, D. Tran, S. Mazzoni, and M. E. Soule. 1997. Response of rodents to habitat fragmentation in coastal southern California. Ecological Applications 7:552-563.

Brown, J. H., and A. Kodric-Brown. 1977. Turnover rates in insular biogeography: effect of immigration on extinction. Ecology 58:445-449.

Burton, T. M., and G. E. Likens. 1975. Salamander populations and biomass in the Hubbard Brook Experimental Forest, New Hampshire. Copeia 1975:541-546.

Butterfield, R. P. 1994. The regional context: land colonization and conservation in Sarapiquí. In L. A. McDade, editor. La Selva: ecology and natural history of a Neotropical rainforest. The University of Chicago Press, Chicago, IL.

Clark, D. B. 1990. La Selva Biological Station: a blueprint for stimulating tropical research. In A. H. Gentry, editor. Four Neotropical Rainforests. Yale University Press, New Haven, CT.

Clarke, K. R., and R. M. Warwick. 2001. Change in marine communities: an approach to statistical analysis and interpretation, $2^{\text {nd }}$ edition. PRIMER-E: Plymouth, UK.

Colwell, R. K. 2004. EstimateS: Statistical estimation of species richness and shared species from samples. Version 7. User's Guide and application published at: hitp: pulrocleorgestimates

Connor, E. F. and E. D. McCoy. 1979. The statistics and biology of the species-area relationship. The American Naturalist 113:791-833. 
Corke, D. 1992. The status and conservation needs of the terrestrial herpetofauna of the windward-islands (West Indies). Biological Conservation 62:47-58.

Cosson, J. F., S. Ringuet, O. Claessens, J. C. de Massary, A. Dalecky, J. F. Villiers, L. Granjon, and J. M. Pons. 1999. Ecological changes in recent land-bridge islands in French Guiana, with emphasis on vertebrate communities. Biological Conservation 91:213-222.

Crump, M. L., and N. J. Scott. 1994. Visual encounter surveys. In W. R. Heyer, M. A. Donnelly, R. W. McDiarmid, L. C. Hayek, and M. S. Foster, editors. Measuring and monitoring biological diversity: standard methods for amphibians. Smithsonian Institution Press, Washington, DC.

Dickman, C. R. 1987. Habitat fragmentation and vertebrate species richness in an urban environment. Journal of Applied Ecology 24:337-351.

Doan, T. M. 2003. Which methods are most effective for surveying rain forest herpetofauna? Journal of Herpetology 37:72-81.

Donnelly, M. A. 1994. Amphibian diversity and natural history. I $n$ L. A. McDade, editor. La Selva: ecology and natural history of a Neotropical rainforest. The University of Chicago Press, Chicago, IL.

Donnelly, M. A., M. H. Chen, and G. C. Watkins. 2005. Sampling amphibians and reptiles in the Iwokrama Forest ecosystem. Proceedings of the Academy of Natural Sciences of Philadelphia 154:55-69.

Driscoll, D. A. 2004. Extinction and outbreaks accompany fragmentation of a reptile community. Ecological Applications 14:220-240.

Duellman, W. E., and L. Trueb. 1986. Biology of amphibians. The John Hopkins University Press, Baltimore, MD.

Fahrig, L., and G. Merriam. 1994. Conservation of fragmented populations. Conservation Biology 8:50-59.

Fauth, J. E., B. I. Crother, and J. B. Slowinski. 1989. Elevational patterns of species richness, evenness, and abundance of the Costa Rican leaf-litter herpetofauna. Biotropica 21:178-185.

Fisher, R. N., and H. B. Shaffer. 1996. The decline of amphibians in California's Great Central Valley. Conservation Biology 10:1387-1397.

Funk, W. C., and L. S. Mills. 2003. Potential causes of population declines in forest fragments in an Amazonian frog. Biological Conservation 111:205-2I4. 
Gascon, C., T. E. Lovejoy, R. O. Bierregaard, J. R. Malcolm, P. C. Stouffer, H. L. Vasconcelos, W. F. Laurance, B. Zimmerman, M. Tocher, and S. Borges. 1999. Matrix habitat and species richness in tropical forest remnants. Biological Conservation 91:223-229.

Gonzalez, A. 2000. Community relaxation in fragmented landscapes: the relation between species richness, area, and age. Ecology Letters 3:441-448.

Grez, A., T. Zaviezo, L. Tschendorf, and L. Fahrig. 2004. A transient, positive effect of habitat fragmentation on insect population densities. Oecologia 141:444-451.

Guariguata, M. R., H. Arias-Le Claire, and G. Jones. 2002. Tree seed fate in a logged and fragmented forest landscape, northeastern Costa Rica. Biotropica 34: 405415 .

Guyer, C. 1994. The reptile fauna: diversity and ecology. In L. A. McDade, editor. La Selva: ecology and natural history of a Neotropical rainforest. The University of Chicago Press, Chicago, IL.

Guyer, C., and M. A. Donnelly. 2005. Amphibians and reptiles of La Selva, Costa Rica, and the Caribbean slope. University of California Press, Berkeley, CA.

Heinen, J. T. 1992. Comparisons of the leaf litter herpetofauna in abandoned cacao plantations and primary rain forest in Costa Rica: some implications for faunal restoration. Biotropica 24:431-439.

Henle, K., K. F. Davies, M. Kleyer, C. Margules, and J. Settele. 2004. Predictors of species sensitivity to fragmentation. Biodiversity and Conservation 13:207-251.

Hokit, D. G., and L. C. Branch. 2003. Habitat patch size affects demographics of the Florida scrub lizard (Sceloporus woodi). Journal of Herpetology 37:257-265.

Jaeger, R. G., and R. F. Inger. 1994. Quadrat sampling. In W. R. Heyer, M. A. Donnelly, R. W. McDiarmid, L. C. Hayek, and M. S. Foster, editors. Measuring and monitoring biological diversity: standard methods for amphibians. Smithsonian Institution Press, Washington, DC.

Jellinek, S., D. A. Driscoll, and J. B. Kirkpatrick. 2004. Environmental and vegetation variables have a greater influence than habitat fragmentation in structuring lizard communities in remnant urban bushland. Austral Ecology 29:294-304.

Laurance, W. F. 1999. Reflections on the tropical deforestation crisis. Biological Conservation 91: 109-117. 
Laurance, W. F., R. O. Bierregaard, C. Gascon, R. K. Didham, A. P. Smith. A. J. Lynam, V. M. Viana, T. E. Lovejoy, K. E. Sieving, J. W. Sites, M. Andersen, M. D. Tocher, E. A. Kramer, C. Restrepo, and C. Moritz. 1997. Tropical forest fragmentation: synthesis of a diverse and dynamic discipline. In W. F. Laurance and R. O. Bierregaard, editors. Tropical forest remnants: ecology, management, and conservation of fragmented communities. University of Chicago Press, Chicago, IL.

Laurance, W. F., T. E. Lovejoy, H. L. Vasconcelos, E. M. Bruna, R. K. Didham, P. C. Stouffer, C. Gascon, R. O. Bierregaard, S. G. Laurance, and E. Sampaio. 2002. Ecosystem decay of Amazonian forest fragments: a 22-year investigation. Conservation Biology 16:605-618.

Lehtinen, R. M., J-B. Ramanamanjato, and J. G. Raveloarison. 2003. Edge effects and extinction proneness in a herpetofauna from Madagascar. Biodiversity and Conservation 12:1357-1370.

Lima, M. G., and C. Gascon. 1999. The conservation value of linear forest remnants in central Amazonia. Biological Conservation 91:241-247.

Lomolino, M. V., and M. D. Weiser. 2001. Towards a more general species-area relationship: diversity on all islands, great and small. Journal of Biogeography 28:431-445.

Luck, G. W., and G. C. Daily. 2003. Tropical countryside bird assemblages: richness, composition, and foraging differ by landscape context. Ecological Applications 13:235-247.

MacNally, R., and G. W. Brown. 2001. Reptiles and habitat fragmentation in the boxironbark forests of central Victoria, Australia: predictions, compositional change, and faunal nestedness. Oecologia 128:116-125.

Margules, C. R., A. O. Nicholls, and R. L. Pressey. 1988. Selecting networks of reserves to maximise biological diversity. Biological Conservation 43:63-76.

Marsh, D. M., and P. B. Pearman. 1997. Effects of habitat fragmentation on the abundance of two species of leptodactylid frogs in an Andean montane forest. Conservation Biology 11:1323-1328.

Matlock, R. B., D. Rogers, P. J. Edwards, S. G. Martin. 2002. Avian communities in forest fragments and reforestation areas associated with banana plantations in Costa Rica. Agriculture, Ecosystems and Environment 91:199-215. 
McDade, L. A., and G. S. Hartshorn. 1994. La Selva Biological Station. In L. A. McDade, editor. La Selva: ecology and natural history of a Neotropical rainforest. The University of Chicago Press, Chicago, IL.

McGarigal, K., and S. A. Cushman. 2002. Comparative evaluation of experimental approaches to the study of habitat fragmentation effects. Ecological Applications 12:335-345.

Miyamoto, M. M. 1982. Vertical habitat use by Eleutherodactylus frogs (Leptodactylidae) at two Costa Rican localities. Biotropica 14:141-144.

Murcia, C. 1995. Edge effects in fragmented forests: implications for conservation. Trends in Ecology and Evolution 10:58-62.

Pearman, P. B., A. M. Velasco, and A. Lopez. 1995. Tropical amphibian monitoring: a comparison of methods for detecting inter-site variation in species composition. Herpetologica 51: 325-335.

Pineda, E., and G. Halffter. 2004. Species diversity and habitat fragmentation: frogs in a tropical montane landscape in Mexico. Biological Conservation 117:499-508.

Pough, F. H. 1980. The advantages of ectothermy for tetrapods. American Naturalist 115:92-112.

Reagan, D. P. 1996. Anoline lizards. In D. P. Reagan and R. B. Waide, editors. The food web of a tropical rain forest. University of Chicago Press, Chicago, IL.

Rothermel, B. B., and R. D. Semlitsch. 2002. An experimental investigation of landscape resistance of forest versus old-field habitats to emigrating juvenile amphibians. Conservation Biology 16:1324-1332.

Sanchez-Azofeifa, G. A., C. Quesada-Mateo, P. Gonzalez-Quesada, S. Dayanandan, and K. S. Bawa. 1999. Protected areas and conservation of biodiversity in the tropics. Conservation Biology 13:407-411.

Sarre, S., G. T. Smith, and J. A. Meyers. 1995. Persistence of two species of gecko (Oedura reticulata and Gehyra variegata) in remnant habitat. Biological Conservation 71:25-33.

Saunders, D.A., R.J. Hobbs, and C.R. Margules. 1991. Biological consequences of ecosystem fragmentation: a review. Conservation Biology 5:18-30.

Savage, J. M. 2002. The amphibians and reptiles of Costa Rica. The University of Chicago Press, Chicago, IL. 
Schlaepfer, M. A. 2003. Successful lizard eggs in a human-disturbed habitat. Conservation Ecology 137:304-311.

Schlaepfer, M. A., and T. A. Gavin. 2001. Edge effects on lizards and frogs in tropical forest fragments. Conservation Biology 15:1079-1090.

Schoereder, J. H., C. Galbiati, C. R. Ribas, T. G. Sobrinho, C. F. Sperber, O. DeSouza, and C. Lopes-Andrade. 2004. Should we use proportional sampling for speciesarea studies? Journal of Biogeography 31:1219-1226.

Scott, N. J. 1976. The abundance and diversity of the herpetofaunas of tropical forest litter. Biotropica 8:41-58.

Shaffer, M. L. 1981. Minimum population sizes for species conservation. Bioscience 31:131-134.

Slowinski, J. B., B. I. Crother, and J. E. Fauth. 1987. Diel differences in leaf-litter abundances of several species of reptiles and amphibians in an abandoned cacao grove in Costa Rica. Revista Biologica Tropical 35:349-350.

Smith, G. T., G. W. Arnold, S. Sarre, M. Abensperg-traun, and D. E. Steven. 1996. The effect of habitat fragmentation and livestock grazing on animal communities in remnants of gimlet Eucalyptus salubris woodland in the western Australia wheatbelt. II. Lizards. Journal of Applied Ecology 33:1302-1310.

Tocher, M. D., C. Gascon, and B. L. Zimmerman. 1997. Fragmentation effects on a central Amazonian frog community: a ten-year study. $I n \mathrm{~W}$. F. Laurance and R. O. Bierregaard, editors. Tropical forest remnants: ecology, management, and conservation of fragmented communities. University of Chicago Press, Chicago, IL.

Toral, E., P. Feisinger, and M. L. Crump. 2002. Frogs and a cloud-forest edge in Ecuador. Conservation Biology 16:735-744.

Turner, I. M. 1996. Species loss in fragments of tropical rain forest: a review of the evidence. Journal of Applied Ecology 33:200-209.

Vallan, D. 2000. Influence of forest fragmentation on amphibian diversity in the nature reserve of Ambohitantely, highland Madagascar. Biological Conservation 96:3143.

Watling, J. I., and M. A. Donnelly. 2002. Seasonal patterns of reproduction and abundance of leaf litter frogs in a Central American rainforest. Journal of Zoology (London) 258:269-276. 
Watling, J. I., J. H. Waddle, D. Kizirian, and M. A. Donnelly. In press. Reproductive phenology of three lizard species in Costa Rica, with comments on seasonal reproduction of Neotropical lizards. Journal of Herpetology.

Zimmerman, B. L., and R. O. Bierregaard. 1986. Relevance of the equilibrium theory of island biogeography and species-area relations to conservation with a case from Amazonia. Journal of Biogeography 13:133-143. 


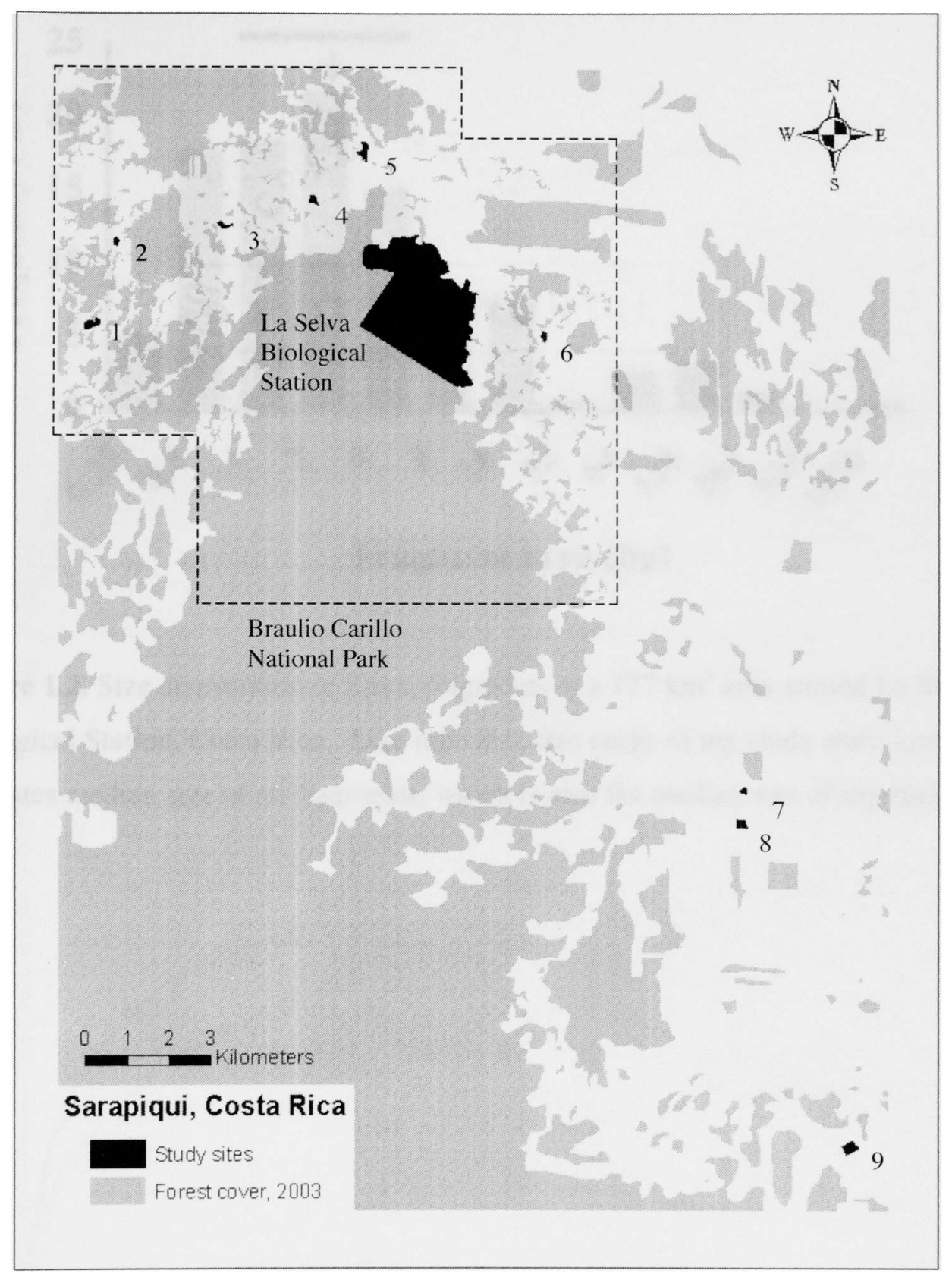

Figure 1.1. Map of forest cover (gray) and study sites (black) in northeastern Costa Rica. Fragments are: (1) Campos, 5.2 ha; (2) Laurel, 1.4 ha; (3) Chilamate, 2.2 ha; (4) Paniagua, 2.6 ha; (5) Casona, 5.4 ha; (6) El Tigre, 2 ha; (7) Rio Frio, 1.8 ha; (8) Colombiano, 4 ha; (9) Finca Araya, 6.9 ha. Reference site is the primary forest area of La Selva Biological Station ( 1100 ha). Dotted line indicates area of high-resolution Quickbird images used for GIS analysis. 


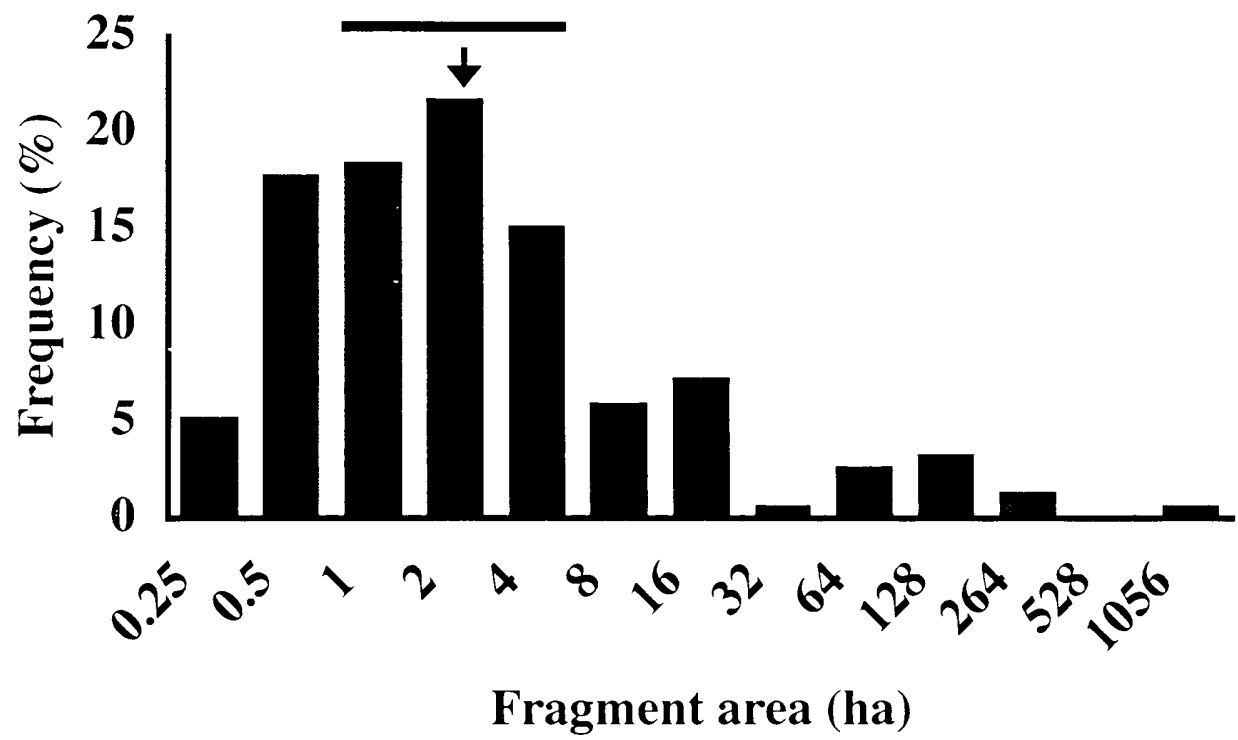

Figure 1.2. Size distribution of forest fragments in a $177 \mathrm{~km}^{2}$ area around La Selva Biological Station, Costa Rica. Line indicates size range of my study sites; arrow indicates median size of all fragments, which is also the median size of my study sites. 

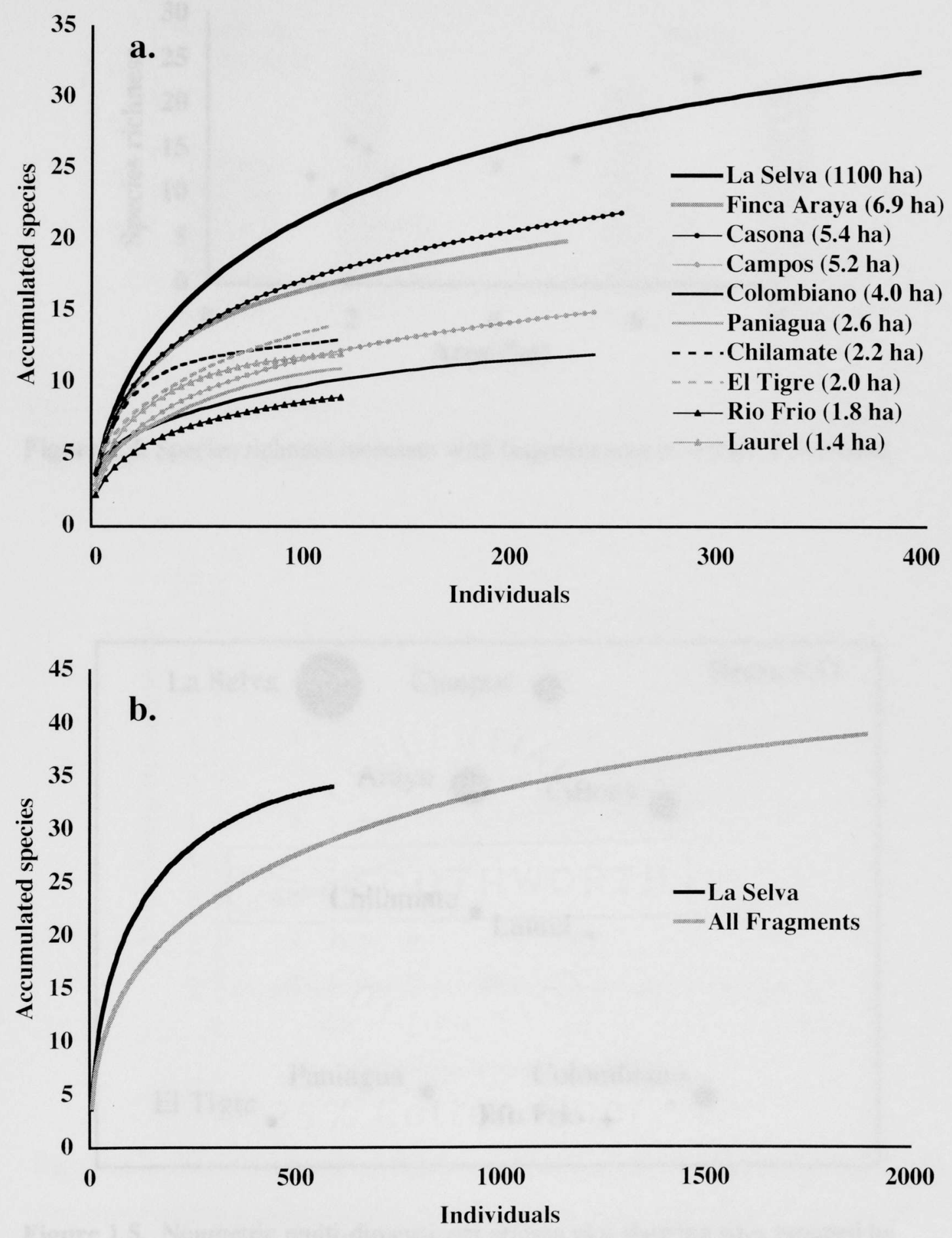

Figure 1.3. Species accumulation by number of individuals for all study sites (a) and for La Selva vs. pooled fragments (b). Constructed using EstimateS (Colwell 2004). 


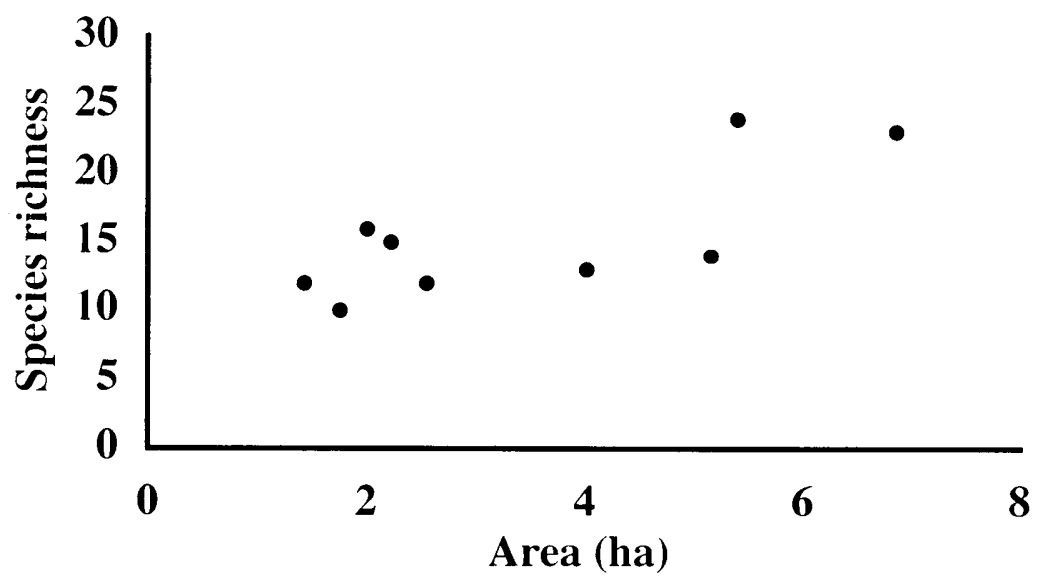

Figure 1.4. Species richness increases with fragment area $\left(r_{\mathrm{v}}=0.67, P=0.049\right)$.

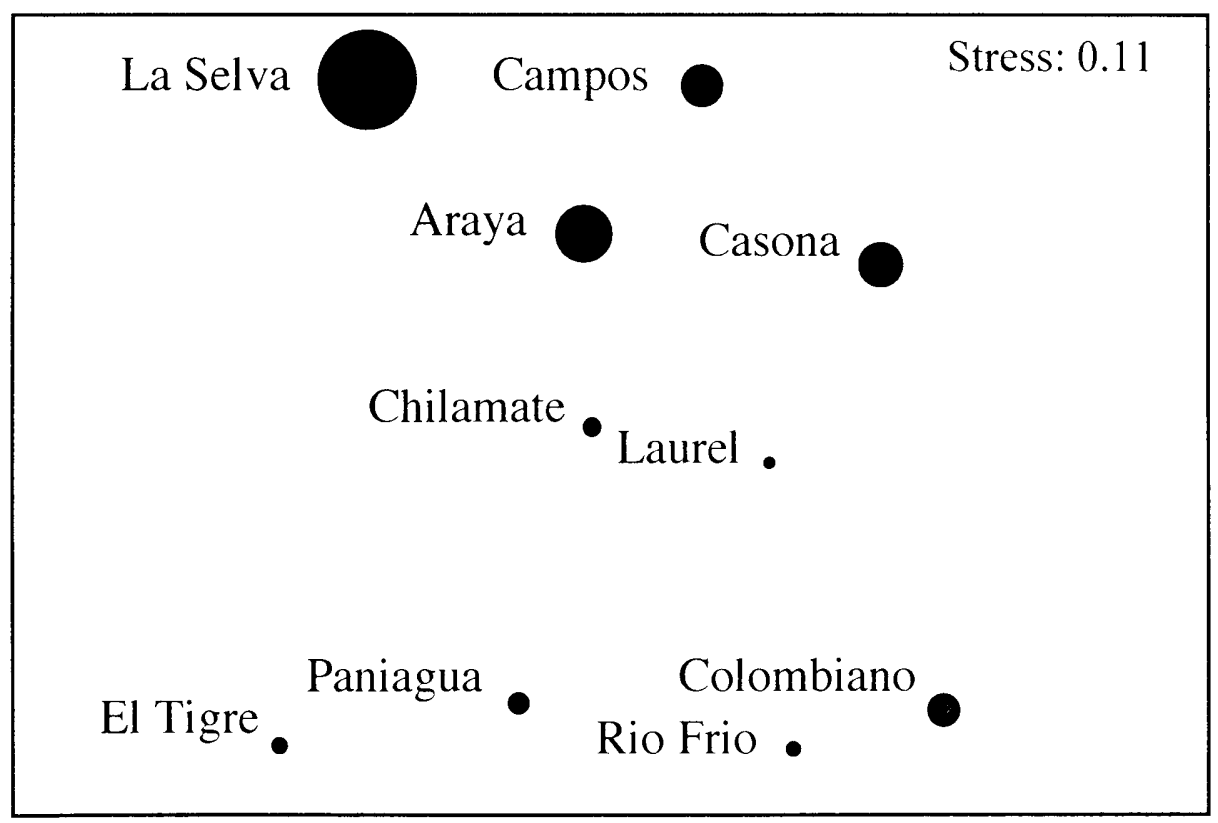

Figure 1.5. Nonmetric multi-dimensional scaling plot showing sites grouped by similarity in community composition. Size of the points is proportional to area of the study sites (except La Selva, which is actually 150 times larger than Araya). 

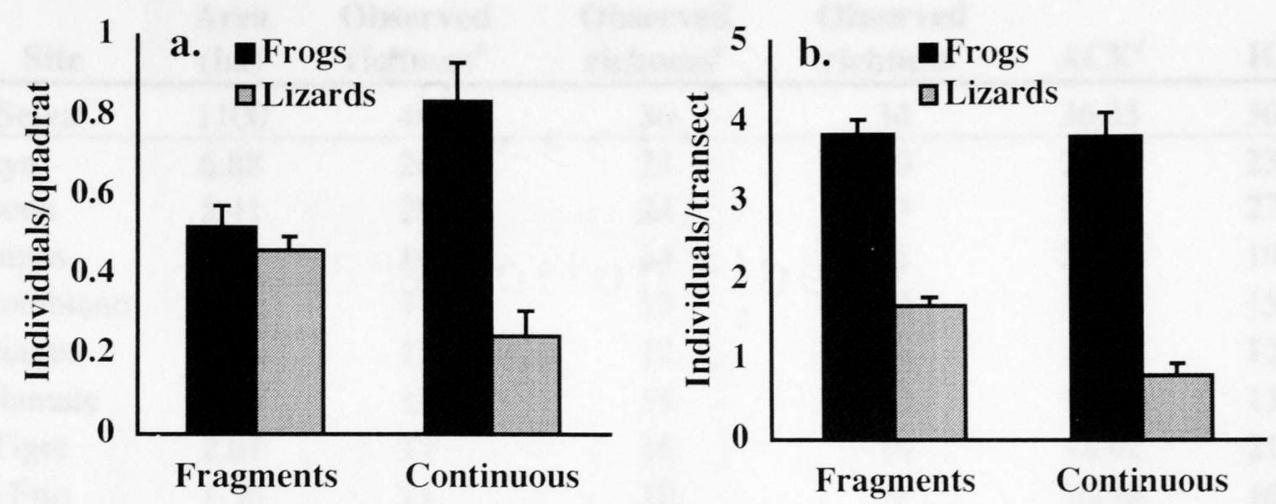

Figure 1.6. Density of frogs and lizards for day sampling (a) and night sampling (b) in fragmented and continuous forest.

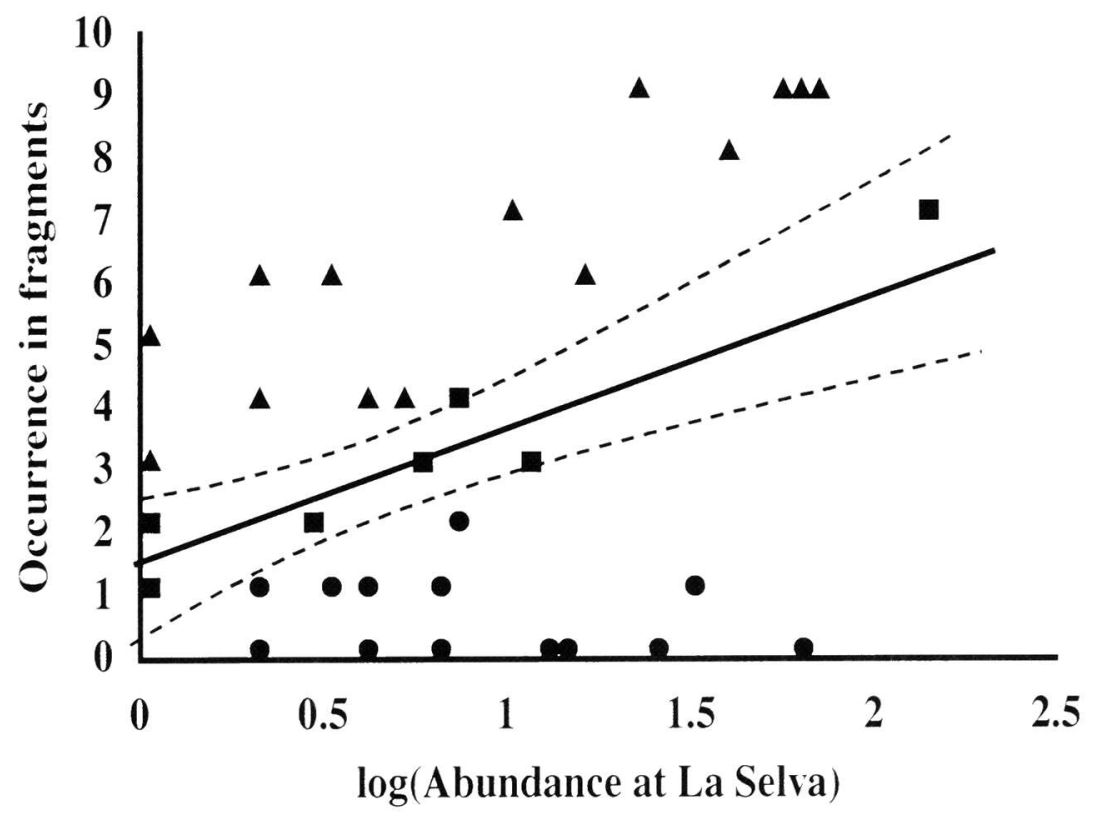

Figure 1.7. There is a positive relationship between species' abundance at La Selva (log-transformed) and the number of fragments in which they occur $\left(r^{2}=0.24 ; \mathrm{df}=49\right.$; $P<0.001)$. Confidence intervals $(x=0.05)$ can be used to delineate two groups of species: those tolerant of fragmentation (triangles) and those sensitive to fragmentation (circles). 


\begin{tabular}{|c|c|c|c|c|c|c|}
\hline Site & $\begin{array}{c}\text { Area } \\
\text { (ha) }\end{array}$ & $\begin{array}{l}\text { Observed } \\
\text { richness }^{b}\end{array}$ & $\begin{array}{l}\text { Observed } \\
\text { richness }^{c}\end{array}$ & $\begin{array}{l}\text { Observed } \\
\text { richness }^{d}\end{array}$ & $\mathbf{A C E} \mathbf{E}^{d}$ & $\mathbf{I C E} \mathbf{E}^{d}$ \\
\hline La Selva & 1100 & 44 & 36 & 34 & 36.35 & 36.10 \\
\hline Araya & 6.88 & 26 & 23 & 20 & 23.43 & 23.44 \\
\hline Casona & 5.41 & 28 & 24 & 23 & 26.95 & 27.02 \\
\hline Campos & 5.17 & 16 & 14 & 15 & 20.18 & 19.55 \\
\hline Colombiano & 4.02 & 15 & 13 & 12 & 13.55 & 15.19 \\
\hline Paniagua & 2.56 & 13 & 12 & 11 & 12.17 & 12.27 \\
\hline Chilamate & 2.23 & 16 & 15 & 13 & 13.66 & 13.68 \\
\hline El Tigre & 2.01 & 17 & 16 & 14 & 18.92 & 21.00 \\
\hline Rio Frio & 1.76 & 11 & 10 & 9 & 10.58 & 10.50 \\
\hline Laurel & 1.43 & 13 & 12 & 12 & 12.45 & 12.35 \\
\hline Spearman's $r$ & & 0.7 & 0.67 & 0.71 & 0.75 & 0.72 \\
\hline$\underline{P}$ & & $\mathbf{0 . 0 3 7}$ & 0.049 & 0.032 & 0.020 & $\mathbf{0 . 0 3 0}$ \\
\hline
\end{tabular}

" not included in correlations

${ }^{b}$ all sampling plus opportunistic sightings

${ }^{c}$ all sampling (transects and quadrats)

${ }^{d}$ transect sampling only

Table 1.1. Area was positively correlated with species richness as measured by observed (total), observed (all sampling), observed (transects), abundance-based (ACE) and incidence-based (ICE) richness estimators for transect data (EstimateS, Colwell 1994). I used only observed richness (all sampling) in further analyses. 
Appendix 1. Study sites and their characteristics. See Methods section of text for full explanations of measurements.

\begin{tabular}{|c|c|c|c|c|c|c|c|c|c|}
\hline Site & $\begin{array}{c}\text { Area } \\
\text { (ha) }\end{array}$ & $\begin{array}{c}\text { Proportion } \\
\text { edge/area } \\
(\mathrm{m} / \mathrm{ha})\end{array}$ & $\begin{array}{l}\text { Distance to } \\
\text { nearest } \\
\text { large forest } \\
(\mathrm{m})\end{array}$ & $\begin{array}{l}\text { Area of } \\
\text { forest } \\
\text { within } 1 \\
\text { km (ha) }\end{array}$ & $\begin{array}{c}\text { Stream } \\
\text { length/area } \\
(\mathbf{m} / \mathbf{h a})\end{array}$ & $\begin{array}{c}\text { Litter dry } \\
\text { mass/30 } \\
\mathrm{cm}^{2}(\mathrm{~g})\end{array}$ & $\begin{array}{c}\text { Canopy } \\
\text { cover } \\
(\%)\end{array}$ & $\begin{array}{c}\text { Understory } \\
\text { openness (m) }\end{array}$ & $\begin{array}{l}\text { DBH } \\
(\mathrm{cm})\end{array}$ \\
\hline Laurel & 1.43 & 377 & 266 & 178 & 0 & 8.98 & 91.01 & 16.53 & 55.4 \\
\hline Rio Frio & 1.76 & 329 & 3266 & 55 & 108 & 17.73 & 90.51 & 10.08 & 46.7 \\
\hline El Tigre & 2.01 & 349 & 1724 & 73 & 0 & 9.77 & 91.58 & 9.25 & 58.8 \\
\hline Chilamate & 2.23 & 433 & 829 & 66 & 149 & 10.77 & 91.49 & 10.36 & 58.4 \\
\hline Paniagua & 2.56 & 395 & 1317 & 41 & 123 & 13.94 & 90.91 & 8.49 & 57.9 \\
\hline Colombiano & 4.02 & 208 & 3079 & 42 & 153 & 11.09 & 88.21 & 8.86 & 70.2 \\
\hline Campos & 5.17 & 269 & 1527 & 199 & 104 & 17.57 & 92.18 & 7.35 & 43.3 \\
\hline Casona & 5.41 & 280 & 2056 & 117 & 79 & 13.28 & 90.51 & 9.35 & 58.2 \\
\hline Araya & 6.88 & 158 & 608 & 95 & 65 & 10.25 & 90.84 & 9.18 & 71.0 \\
\hline La Selva & 1100 & & & & & 9.44 & 91.97 & 11.85 & 61.0 \\
\hline
\end{tabular}


Appendix 2. Total captures for all species, and number of quadrats $(5 \times 5 \mathrm{~m})$ and transects $(50 \times 4 \mathrm{~m})$ sampled, at each site.

\begin{tabular}{|c|c|c|c|c|c|c|c|c|c|c|c|}
\hline & La Selva & $\begin{array}{l}\text { Finca } \\
\text { Araya } \\
\end{array}$ & Casona & Campos & Colombiano & Paniagua & Chilamate & $\begin{array}{c}\text { El } \\
\text { Tigre } \\
\end{array}$ & $\begin{array}{c}\text { Rio } \\
\text { Frio } \\
\end{array}$ & Laurel & Total \\
\hline Quadrats & 98 & 39 & 43 & 40 & +1 & 28 & 28 & 29 & 28 & 28 & \\
\hline Transects & 1.32 & 51 & 57 & 54 & $5+$ & 27 & 27 & 26 & 27 & 27 & \\
\hline Norops limifrons & 78 & 22 & $5+$ & 14 & $1+8$ & $6+$ & 9 & 1.36 & 46 & 34 & 607 \\
\hline Dendrobates pumilio & 168 & +2 & 23 & 99 & & 26 & 70 & 61 & & 14 & 510 \\
\hline Eleutherodactylus fit-ingeri & 59 & 41 & 81 & 10 & 88 & 29 & 36 & 2 & 23 & 19 & .389 \\
\hline Scinar elacochroa & 15 & 9 & 1 & & 68 & & 1.3 & $12+$ & 8 & & 2.38 \\
\hline Eleutherodactylus diastema & 64 & 6 & 21 & 23 & 40 & 22 & 9 & 7 & 7 & 25 & 234 \\
\hline E. ridens & 9 & $H$ & $2+$ & 31 & 21 & & 6 & & 4 & 8 & $1+7$ \\
\hline $\begin{array}{l}\text { Norops humilis } \\
\text { Eleutherodactilus }\end{array}$ & 24 & $1+$ & 29 & 7 & 3 & 6 & 15 & 7 & 3 & $1+$ & 123 \\
\hline bransfordii & +2 & 14 & 6 & 8 & 1.5 & & 1.3 & 7 & 5 & 2 & 112 \\
\hline E. talamancae & 68 & & & & & & & & & & 68 \\
\hline Similisca puma & & 19 & 5 & 12 & 3 & & & & & + & +3 \\
\hline $\begin{array}{l}\text { Scinax boulengeri } \\
\text { Elentherodactilus }\end{array}$ & 2 & 9 & & 2 & & 3 & 5 & 17 & & + & +2 \\
\hline cercusinus & 32 & 2 & & & & & & & & & 34 \\
\hline Norops oxylophuss & 6 & 6 & 6 & & 3 & & 8 & & & & 29 \\
\hline Eleutherodactylus noblei & 11 & 1 & 15 & 1 & & & & & & & 28 \\
\hline Agalychnis saltator & $2+$ & & & & & & & & & & $2+$ \\
\hline Corvtophanes cristatus & 3 & 6 & 5 & + & & & & & & + & 22 \\
\hline Dendrobates auratus & & & 15 & & & 2 & & & & & 17 \\
\hline Sphenomorphus cherriei & 1 & 2 & + & & & 1 & 1 & 3 & 4 & & 16 \\
\hline Elentherodactylus cruentus & 1.3 & & & & & & & & & & 14 \\
\hline E. crassidigitus & 12 & & & & & & & & & & 13 \\
\hline $\begin{array}{l}\text { Centrolenella prosoblepon } \\
\text { Lepiodactylus }\end{array}$ & 6 & & + & 2 & & & & & & & 12 \\
\hline pentadactylus & 5 & 2 & & 1 & & & & & & 2 & 10 \\
\hline Agalychnis callidryas & 4 & 1 & & & & 1 & & 3 & & 1 & 10 \\
\hline Hyla ebraceata & 2 & & & & & & & 8 & & & 10 \\
\hline
\end{tabular}


Eleutherodentilus megacephaluss

Norops carpenteri

Ameiva festiva

Eleutherodactylus mimus

Lepidohlepharis ranthostigina

Norops lemurimus

Bufo melanochloris

Gastrophryne pictiventris

Basiliscus vittatus

Smilisc a baudinii

Bufo haematiticus

Hyla rufitela

Norops capito

Similisca phacota

Cochranella albomaculata

Hoalinobatrachium pulveratum

Rana warszewitschii

Basiliscus plamifrons

Agalvehnis calcarifer

Hola phlebodes

Smilisca sordida

Hyalinobatrachium valerioi

Thecadactylus rapicaudus

Norops biporcatus. 


\title{
Population variability of a leaf-litter herpetofauna at La Selva, Costa Rica: seasonal and long-term trends
}

\author{
Kristen E. Bell
}

\begin{abstract}
I compared population densities of leaf-litter amphibians and reptiles across 35 years at La Selva Biological Station, a lowland wet forest site in Costa Rica. La Selva has received more attention from herpetologists than nearly any other Neotropical site, and because researchers have used standard sampling methods, this site provides a unique opportunity to compare quantitative data on populations over time. My objectives were to determine whether seasonal patterns of abundance are consistent across years, to assess changes in density and relative abundance of amphibians and reptiles over the last four decades, and to compare these changes between amphibians and reptiles to see if they support the hypothesis that amphibians have declined at La Selva. Seasonal abundance patterns were examined for 1973-74 (13 months) and 2003-04 (6 months). In 1973-74 there was a large peak in abundance for most species in March and April, corresponding to the end of the dry season; this peak was absent in 2003-04. and overall densities were an order of magnitude lower than those in 1973-74. Mean densities were calculated for available months between 1970 and 2004, both in primary forest $(n=35)$ and abandoned cacao plantation $(n=15)$. Most common species of both frogs and lizards in this assemblage demonstrated significant decreases in density over the 35-year period. Members of this assemblage depend on a similar set of habitat and dietary resources, which may explain the similar response across taxa. My results may indicate either
\end{abstract}


widespread faunal declines or natural population fluctuations but do not support the hypothesis of an amphibian-specific decline at this site.

\section{Introduction}

Since 1989, amphibian declines have been documented in both human-impacted and apparently pristine sites around the world (Wake 1989; Houlahan et al. 2000). Causes of amphibian declines, as summarized in Young et al. (2001), include climate change, habitat modification and fragmentation, introduced species, UV-B radiation, chemical contaminants, acid precipitation, disease, and trade. Direct anthropogenic impacts such as habitat destruction and modification are the primary threats to amphibian populations (Blaustein et al. 1994; Alford and Richards 1999). However, much attention has been focused on declines in pristine sites, since these "mysterious" declines may implicate widespread, invisible anthropogenic influences such as global climate change (Donnelly and Crump 1998). It has become clear that the causes of decline vary according to individual communities and species, and in most cases include synergistic effects of several factors (Carey et al. 1999; Blaustein and Kiesecker 2002). The primary difficulty in pinpointing declines has been distinguishing actual declines and disappearances from natural fluctuations in population size (Pechmann et al. 1991). The magnitude of observed natural population fluctuation depends on variability in recruitment, activity patterns, and detectability (Alford and Richards 1999). For instance, populations of many seasonal aquatic breeders may skip breeding in years of unfavorable climate (Skelly et al. 2003). Populations with highly variable recruitment tend to 
experience occasional years of large population increase followed by several years of declines (Alford and Richards 1999).

Temperate amphibian populations can experience high variation in abundance among years (Pechmann et al. 1991). Populations of pond-breeding species tend to have a larger variance in population size than stream-breeding or terrestrial direct-developing species (in a review of 617 population studies lasting $\geq 5$ years, Green 2003). Long-term datasets for tropical amphibian populations are extremely rare (Young et al. 2001). Documented among-year differences in tropical amphibian populations are predominantly in the range of 2-fold to 4 -fold, with occasional reports of much larger change (Rand et al. 1983; Table 2.1). No study has found inter-annual tropical population fluctuations to match the 2-3 orders of magnitude reported for some temperate populations (Pechmann et al. 1991). Populations of tropical anurans can also exhibit great monthly variation in population density as a result of seasonal variation in rainfall and litter depth. Maximum population change within a year varied from 3 -fold in Panama and Peru (Toft 1980; Rodriguez 1992) to over 7-fold in Amazonia (Allmon 1991), in some cases exceeding variation among years (Duellman 1995; Table 2.2). Tropical amphibian declines are usually reported as disappearances by workers revisiting a collection site (e.g. Heyer et al. 1988; La Marca and Reinthaler 1991; Coloma 1995; Laurance 1996; Lips et al. 2004). Pounds et al. (1997) constructed a null model to test for amphibian decline based on the number of species disappearing from a site. Ideally, declines should be identified before species start to disappear, by noting changes in density over several years (e.g.. Martinez-Solano et al. 2003). Due to high among-year variability, studies that examine 10 years or more of sampling data are the most useful. 
Because tropical amphibian populations also experience great seasonal variation in abundance, between-year comparisons should try to examine data collected during the same month or season in each year.

Population studies of lizards offer a potentially good source of comparison for amphibian declines. In the tropics, many lizards share habitat and food resources with frogs (Vitt and Caldwell 1994); therefore, they may be affected similarly by changes in resource availability. Several species of frogs and lizards in Costa Rica showed similar seasonal variation in abundance (Lieberman 1986). Monitoring lizard as well as amphibian densities in tropical sites could provide a benchmark for detecting amphibian declines, although at some sites lizards may also be in decline (Gibbons et al. 2000). Two species of anoles declined and disappeared over a 15-yr period in Monteverde, Costa Rica (Pounds 2000). Population variability of tropical lizards ranges from almost no difference (Hirth 1963) to very large differences (Andrews 1991) among years (Table 2.1).

I compare population densities of amphibians and reptiles (focusing on frogs and lizards) across 35 years at La Selva Biological Station, a lowland wet forest site in Costa Rica. La Selva has been the focus of herpetological research for decades (Guyer 1990; Guyer 1994; Donnelly 1994; Savage 2002; Guyer and Donnelly 2005), and so provides a unique opportunity to compare quantitative data on populations over time. This comparison is made possible by the consistent use of a standard sampling method, the leaf-litter quadrat, by generations of researchers. Although my interpretation is limited by the variation in sampling timing and intensity, this is nevertheless one of the most complete datasets for density of a tropical herpetofauna across decades. 
My specific objectives were: 1) To determine whether seasonal patterns of abundance of the leaf-litter herpetofauna at La Selva are consistent across years; 2) To assess changes in density and relative abundance of amphibians and reptiles over the last four decades at La Selva; and 3) To compare these changes between amphibians and reptiles to see if any declines are amphibian-specific.

\section{Methods}

La Selva Biological Station is a preserve owned by the Organization for Tropical Studies in the Caribbean lowlands of Costa Rica. La Selva is located in Sarapiquí canton in the province of Heredia, at the confluence of the Puerto Viejo and Sarapiquí rivers $\left(10^{\circ} 26^{\prime} \mathrm{N}, 83^{\circ} 59^{\prime} \mathrm{W}\right)$; for a complete description of the site, see McDade and Hartshorn (1994). About $70 \%$ of La Selva's 1,600 hectares is primary forest, and it is adjacent to the 45,000-ha Braulio Carrillo National Park. Reptiles and amphibians have been sampled at this site since the 1950s (Guyer 1994; Guyer and Donnelly 2005).

I analyzed two datasets, one from primary forest and one from abandoned cacao plantation. I considered only data collected from leaf-litter plots sampled during the day at La Selva Biological Station. Quadrat sampling provides fairly accurate density estimates of organisms inhabiting the leaf litter (Jaeger and Inger 1994). The leaf-litter herpetofauna at La Selva comprises roughly 16 frogs, 11 lizards, and a large number of snakes, most of which reproduce terrestrially (Donnelly 1994; Guyer 1994).

Sources of data for forest and cacao are summarized in Table 2.3. Forest sampling data came from the following sources: 1) Scott (1976) sampled in March and August, 1970, and March and July, 1971. 2) An extensive collection was made by C. F. 
Dock, C. S. Lieb, J. J. Talbot, and R. W. Vandevender, each month from December, 1973 to December, 1974. Data from this collection has been presented by Lieberman (1986), Guyer (1986), Donnelly (1989, 1999), Watling and Donnelly (2002), and Watling et al. (in press). 3) Heinen (1992) sampled from January to March, 1990. 4) Whitfield and Pierce (2005) sampled in April and May, 2000. 5) M. Sasa sampled in March, 2002. 6) K. E. Bell sampled monthly from October, 2003 to April, 2004, with preliminary data from June, 2003. 6) Data from graduate and undergraduate courses run by the Organization for Tropical Studies are also included (from 1977, 1982, 1984, 2000, 2003, and 2004). These projects were, by their nature, short-term sampling efforts, concerned primarily with learning field methodologies. However, OTS projects are usually supervised by professors who are very familiar with the system and performed by highly motivated students, and the value of such sources should not be overlooked. All analyses were conducted first with data sets excluding OTS course projects and then with all data sets together. Cacao sampling data came from the following sources: 1) The previously described collection by Dock et al. from December, 1973 to December, 1974. 2) Fauth et al. (1989) sampled in September, 1985. 3) Heinen (1992) sampled from January to March, 1990. 4) Donnelly (unpublished data) sampled in September 1996. March 1998. and May 1999. 5) Whitfield and Pierce (2005) sampled in April and May, 2000. 6) One OTS course sampled in 1982.

Two of the studies have monthly samples for at least a 6-month period, making seasonal comparisons possible. Mean monthly density was plotted for the 1974 and 2004 datasets to look for seasonal patterns in relative abundance. For one species, Norops 
humilis, an additional dataset was examined (Guyer 1988). Seasonal patterns in rainfall and leaf litter accumulation were also explored.

To examine changes in density across years, log-transformed mean densities were calculated for each month for which we had primary forest sampling data $(n=29$; with OTS course data $n=35$ ). Log-transformed mean monthly densities were used for the cacao dataset, except for the 1974 data, for which the mean of each two consecutive months was reported due to low sampling intensity (one plot/month; $n=15$ ). The following groups were analyzed: all reptiles and amphibians, all frogs, all lizards, and the abundant species Dendrobates pumilio, Eleutherodactylus bransfordii, E. megacephalus, E. diastema, E. talamancae, E. mimus, Gastrophryne pictiventris, Bufo haematiticus, Norops humilis, N. limifrons, Lepidoblepharis xanthostigma, and Sphenomorphus cherriei. These species are leaf-litter inhabitants with terrestrial reproduction, with the exception of G. pictiventris and B. haematiticus, which are aquatic breeders, and $E$. diastema, which is semi-arboreal. Mean monthly densities were analyzed across all years using nonparametric Kendall's tau-b correlations, which have been used previously to detect faunal declines (Pechmann and Wilbur 1994; Pounds 2000).

Relative abundance of species was calculated for each year from primary forest data to examine changes in community composition. I analyzed change in community composition over time using a Mantel test, a technique that tests for correlations between two distance matrices (Manly 1991). For the species composition similarity matrix I used a Bray-Curtis dissimilarity index of standardized densities of the 12 most common species and for the temporal distance matrix I used the number of months between 
sampling events. Each month of sampling was considered an independent sampling event. I conducted 999 randomizations and calculated a Spearman's coefficient.

These data may be subject to several biases as a result of sampling differences among studies. Obviously, different observers were responsible for data collection across studies. Although all studies used leaf-litter quadrat sampling, quadrat size varied from 16 to $144 \mathrm{~m}^{2}$ among years. For primary forest data, plot size was significantly correlated with time (Spearman, $r_{s}=-0.50, P=0.002$ ), which could confound my other analyses. Plot size in cacao was not correlated with time $\left(r_{1}=-0.21, P=0.46\right)$. I analyzed reptile and amphibian densities according to both year and plot size using multiple regression, for both forest and cacao datasets. Finally, sampling in each year occurred in different numbers and combinations of months. For this reason, I wanted to make sure that acrossyear differences were not actually the result of monthly variation. I plotted densities for those months with more than three appearances in the datasets: January, February, and March. To determine the relative effects of month versus year on change in community composition, I ran two additional Mantel tests, on with a temporal distance matrix of difference between months (ignoring year) and one with a temporal distance matrix of difference between years (ignoring month).

\section{Results}

Seasonal trends

Between December 1973 and December 1974, densities of reptiles and amphibians peaked in March and April. Between October 2003 and April 2004, densities were highest in October and November, with a much smaller peak in March and April 
(Fig. 2.1). For the common lizard Norops humilis, abundance in 1983 followed the 1974 pattern (Fig. 2.2). The largest changes in density (excluding zeros) for common species in both years are reported in Table 2.4. In 1974, leaf litter accumulation peaked in May and rainfall peaked in July (Fig. 2.1); leaf-litter volume was correlated with total reptile and amphibian density (Spearman, $r_{\mathrm{s}}=0.79, P=0.001$ ). In 2004, leaf litter was greatest in November and rainfall greatest in October and December (Fig. 2.1); leaf litter mass was not correlated with density of amphibians and reptiles $\left(r_{\mathrm{s}}=-0.03, P=0.96\right)$. Annual trends

Many species significantly declined in density over the 35-year period in primary forest (Fig. 2.3). For the limited dataset (using each month as a datapoint, $n=29$ ), nonparametric correlations indicated significant declines in density of all herpetofauna, all frogs, all lizards, E. bransfordii, D. pumilio, E. megacephalus, E. diastema, E. mimus, B. haematiticus, $N$. humilis, N. limifrons, L.xanthostigma, and S. cherriei (Table 2.5). Relationships were not significant for G. pictiventris or E. talamancae. When OTS course data were included in the analysis $(n=35)$, declines remained significant for all herpetofauna, E. bransfordii, D. pumilio, N. humilis, and $N$. limifrons (the only species for which I had data; Table 2.5). In order to determine the role of monthly variation in accounting for declines across years, I plotted densities for January $(n=4)$, February $(n=$ 4), and March $(n=5)$ across years. Although these data are insufficient for statistical analysis, the trends for each month reflect the trends for the entire dataset (Fig. 2.4). For the primary forest data, both year $(F=40.20, P<0.001)$ and quadrat size $(F=4.18, P=$ 0.050 ) were significant in a multiple regression of amphibian and reptile density on those variables: the interaction between year and quadrat size was also significant $(F=11.43, P$ 
$=0.002)$. For the cacao dataset, year was significant $(F=32.80, P<0.001)$ but plot size was not $(F=0.02, P=0.88)$; neither was the interaction $(F=0.31, P=0.59)$. Significant declines across species were also present in the abandoned cacao dataset $(n=15$; Fig. 2.5) for all amphibians and reptiles, all frogs, all lizards, E. bransfordii, D. pumilio, $N$. humilis, $N$. limifrons, and L. xanthostigma. Changes in density were not significant for $S$. cherriei, E. megacephalus, or E. diastema (Table 2.5).

The relative abundance of species changed across years in primary forest (Fig. 2.6). In 1971, 1974, and 1990, E. bransfordii was the most abundant species, followed by $D$. pumilio. In 2000 and 2004, D. pumilio replaced E. bransfordii as the most abundant species. Norops humilis and $N$. limifrons remained moderately abundant throughout the period. Lepidoblepharis xanthostigma and E. megacephalus were moderately abundant in 1971-1990 and uncommon to absent in 2000-2004. Sphenomorphus cherriei was moderately abundant in 1971-1974, but not observed in 1990-2004. Change in community composition across time (considering only the 12 most abundant species) was significant according to a Mantel test $\left(r_{1}=0.577, P<0.001\right)$. Differences were significant by year $\left(r_{s}=0.578, P<0.001\right)$ but not by month $\left(r_{s}=-\right.$ $0.069, P=0.126)$.

\section{Discussion}

The leaf-litter herpetofaunal community at La Selva exhibits great variability in the abundance of frogs and lizards both seasonally and annually. The forest at this site is also very dynamic, with very high tree mortality and turnover rates compared to other tropical forests (Lieberman and Lieberman 1987). Densities of amphibians and reptiles 
vary across months, although not all years show marked seasonal differences. Population densities and relative abundances of frog and lizard species have changed over the past decades. The most striking trend emerging from this 35 -year view is an apparent decline in leaf-litter reptile and amphibian density in general, and in one species of leptodactylid, Eleutherodactylus bransfordii, in particular.

$\underline{\text { Seasonal trends }}$

Monthly variation in density for the common frog and lizard species in 1974 and 2004 was similar in magnitude to that reported for other tropical assemblages (Table 2.2). Litter frogs and lizards at La Selva studied in 1974 and 2004 demonstrated maximum changes of roughly 4-fold and 6-fold, respectively. Maximum within-year changes in density reported for other tropical frogs and lizards range from 3-fold to 7.6-fold (Toft 1980; Guyer 1988; Allmon 1991; Duellman 1995; Stewart 1995), with the exception of two frog species in Panama that changed by 1-2 orders of magnitude over the course of a year (Toft et al. 1982).

Do these fluctuations follow a predictable seasonal pattern? In 1974, both frogs and lizards increased dramatically at the end of the dry season, in March and April (Lieberman 1986); the same pattern held for $N$. humilis in 1982-83 (Guyer 1988). In contrast, frogs and lizards in 2003-04 displayed highest densities in October and November (Fig. 2.2). Although available data are limited, these results suggest the presence of a peak in abundance at the end of the dry season in some but not all years. Although the seasonal pattern was different among years, within each year most species followed the same abundance patterns. Both frogs and lizards in this leaf-litter 
assemblage seem to respond in the same way to resource availability or other environmental cues.

Increases in observed abundance originate either from recruitment or changes in activity patterns. In many cases, seasonal patterns in density are mostly (Toft et al. 1982; Donnelly 1989; Allmon 1991; Rodriguez 1992; Stewart 1995) or partly (E. bransfordii at La Selva; Donnelly 1999) the result of seasonal pulses of recruitment. On the other hand, sometimes highly seasonal recruitment does not result in corresponding patterns in density (four litter frogs at La Selva; Watling and Donnelly 2002). In one case, density was highest during the months with least recruitment ( $N$. humilis at La Selva; Guyer 1986). There was insufficient data to estimate recruitment for 2004 . However, from these scattered examples it seems that recruitment is often seasonal in tropical lizards and amphibians, and that it may or may not lead to evident patterns in abundance through the year. Timing of recruitment and/or activity may be tied to litter depth, which is usually greatest during the dry season and dry-wet transition at La Selva (Frankie et al. 1974). Leaf litter accumulation was correlated with reptile and amphibian density in 1973-73 but not in 2003-04. Leaf litter provides both oviposition sites and habitat for arthropods (prey), which also reach their highest densities during the dry season and dry-wet transition in this part of Central America (Toft 1980; Lieberman and Dock 1982). The amount of litterfall is dependent on annual weather conditions, especially the timing and amount of rainfall (Frankie et al. 1974). Therefore, a large, seasonal peak in recruitment of frogs and lizards may occur only in certain years when conditions are favorable. In general, tropical seasonality is less predictable (or less understood) than we realize. 


\section{Annual trends}

Population fluctuations among years at La Selva were larger than some reported from other tropical sites, with maximum changes of 18-fold for frogs and 14-fold for lizards. In comparison, other tropical anurans experienced maximum changes of 2.5-fold to 3.8-fold across years (Inger and Voris 1993; Duellman 1995; Woolbright 1996), with the exception of much greater change in one frog and one lizard from BCI, Panama (Rand et al. 1983; Andrews 1991). Norops limifrons displayed an 11-fold change over the 30-year period; this is much more stable than a population of Norops limifrons at Barro Colorado Island, Panama, which varied from 0 to 17.4 individuals $/ 100 \mathrm{~m}^{2}$ over a 19-year period (Andrews 1991). The BCI population appears to be exceptionally variable compared with other temperate, subtropical, and tropical lizard populations (Schoener 1985; Andrews 1991). Much larger fluctations in amphibian populations (e.g., Pechmann et al. 1991) may reflect larger errors in detection probability. Pond-breeding species only emerge to breed when conditions are right, sometimes skipping a year entirely (Skelly et al. 2003), whereas leaf-litter species are present year-round.

Although the population fluctuations I report fall within the range of those reported from other tropical sites, in this case the changes are predominantly negative. Eleutherodactylus bransfordii has declined from more than 10 individuals per $100 \mathrm{~m}^{2}$ in 1970 to less than 1 per $100 \mathrm{~m}^{2}$ in 2004. Eleutherodactylus bransfordii was the most abundant species in 1970,1971,1974, and 1990; in 2000 and 2004 it was much less abundant than D. pumilio. Attempts have been made to identify characteristics common to declining species, in order to focus conservation efforts on such species. Within temperate regions, species with highly variable population sizes and obligate dispersal 
across different habitat types, such as pond-breeding amphibians, appear to be most at risk (Green 2003). From the known instances of tropical amphibian decline, riparian species at middle to high elevations appear most at risk for extirpation (Lips et al. 2003). Eleutherodactylus bransfordii is assumed to breed terrestrially, by depositing eggs in the leaf litter, although reproduction has never been described other than "breeds at night" (Scott 1983). Reproductive adults and small juveniles were found throughout the year in 1974, indicating that reproduction occurs year-round (Donnelly 1999). As an abundant, terrestrially-breeding, lowland species, E. bransfordii should be in the lowest risk category for declines according to current theory. Most tropical declines have occurred at higher elevations (Lips 2003), and both temperate and tropical amphibian declines affect mainly aquatic-breeding species, especially narrowly endemic ones (Green 2003; Lips 2003).

Although E. bransfordii suffered the most dramatic decrease in density, almost the entire assemblage of litter frogs and lizards exhibited the same pattern. Of the other common species examined, five of seven frogs and all four lizards experienced significant negative trends in population over time (Figs. 2.3, 2.5). It is important to note that I only detected changes in abundant species across time; because of differences in sampling intensity among studies, I could draw no conclusions about uncommon to rare species. However, there is anecdotal evidence that at least one rare species, Eleutherodactylus ranoides, has disappeared from the site.

In addition to the negative population trends, I found a significant interaction between year and quadrat size for the primary forest data. It seems unlikely, however, that declines are actually an artifact of changing litter plot size, for several reasons. First, 
any plot-size effect should result in slightly lower (rather than higher) densities of animals in larger quadrats, because the probability of escape increases with plot size. Furthermore, the relationship between year and population density is much stronger than that between plot size and density. Finally, plot size in the cacao dataset is not correlated with time, and populations in cacao display the same negative trends as those in primary forest. Negative relationships in density across years are also not attributable to monthly variation. When population densities for individual months were graphed separately, population trends remained negative (Fig. 2.4). Community composition varied significantly by year but not by month according to Mantel tests.

Because both frogs and lizards exhibit declines of similar magnitude, these data do not reflect amphibian-specific declines. Members of this assemblage depend on a similar set of habitat and dietary resources, which may explain the similar response across taxa. No simple reason for the observed negative trends stands out, but I suggest the following factors: 1) Climate. The annual mean of minimum daily temperature increased between 1982 and $2004\left(r^{2}=0.492, P<0.001 ;\right.$ D. A. Clark dataset $)$; total annual rainfall also increased during that time $\left(r^{2}=0.265, P=0.012\right)$, and the proportion of days with no rainfall decreased between 1970 and $2004\left(r^{2}=0.670, P<0.001\right.$; OTS dataset, http://www.ots.ac.cr/en/laselva/metereological.shtml; Fig. 2.8). Although the annual mean of minimum daily temperature varied only $1.75^{\circ} \mathrm{C}$ between 1984 and 2000 , it was significantly negatively correlated with tree growth during the same period (Clark et al. 2003), indicating that the current climatic shift is strong enough to influence forest dynamics. The increasingly warmer and wetter conditions of the past two decades could influence litter accumulation by speeding decomposition rates (D. A. Clark, personal 
communication). This in turn could affect prey and reproductive habitat availability for the litter herpetofauna. Climate change could also make animals more susceptible to disease or parasites (Donnelly and Crump 1998). Negative effects of climate change on diverse faunal groups have been documented at high elevation sites in the tropics (Pounds et al. 1999) but not in lowland sites. 2) Human impact on the forest. La Selva's annual visitation rate by educational groups, scientists, and tourists has steadily risen over the past few decades; the number of person-days more than doubled between 1982 and 1991 (McDade and Hartshorn 1994), and then doubled again by 2004 to a total of 33,000 (OTS). In addition to the impacts of trail and forest use, people can be unwitting vectors of exotic species and diseases. Scientific collecting of reptiles and amphibians was also common in the past. 3) Isolation effects. There is some evidence that metapopulation dynamics are vitally important for long-term persistence or stability of herpetofaunal populations (Alford and Richards 1999). The Sarapiquí region has undergone increasing fragmentation during the last three decades: total forest cover decreased from $55 \%$ of the landscape in 1976 to $34 \%$ in 1996 . The number of forest islands more than doubled over this time period, while the average size of fragments decreased from $0.95 \mathrm{~km}^{2}$ to 0.25 $\mathrm{km}^{2}$ (Sanchez-Azofeifa et al.1999). La Selva is essentially an island of lowland rain forest (Braulio Carrillo National Park is montane forest connected to La Selva via a steep elevational gradient). If metapopulation dynamics operate on a spatial scale nearly the size of or larger than the La Selva reserve, then the isolation of La Selva within the Caribbean lowlands would effectively eliminate metapopulation dynamics, and could plausibly contribute to drastic population declines. 4) Area or edge effects. La Selva's isolation may leave it vulnerable to other impacts commonly experienced by forest 
fragments. Communities in forest fragments are affected by the decreased area of forest as well as physical and biotic changes associated with edge formation. Although La Selva is fairly large, it may be in a state of "faunal relaxation" and communities may be shifting in favor of edge-adapted species.

In conclusion, my data either indicate widespread faunal declines or add to our knowledge of the natural range of population fluctuations in tropical herpetofaunas. Simultaneous negative trends in the density of leaf litter frogs and lizards at La Selva resemble the declines across taxa at Monteverde (Pounds et al. 1999) rather than amphibian-specific declines. In Monteverde, declines were apparently linked to changes in timing and quantity of rainfall, but at La Selva causality remains unclear. Continued monitoring at this site, of arthropods and leaf litter as well as the herpetofauna, is clearly warranted. La Selva is one of only two large areas of Caribbean lowland forest remaining in Costa Rica; its value to the conservation of reptiles and amphibians is dependent on our gaining a better understanding of the factors influencing long-term population change. 


\section{References}

Alcala, A. C., and W. C. Brown. 1967. Population ecology of the tropical scincoid lizard, Emoia atrocostata, in the Phillipines. Copeia 1967:596-604.

Alford, R. A., and S. J. Richards. 1999. Global amphibian declines: a problem in applied ecology. Annual Review of Ecology and Systematics 30:133-165.

Allmon, W. D. 1991. A plot study of forest floor litter frogs, Central Amazon, Brazil. Journal of Tropical Ecology 7:509-522.

Andrews, R. M. 1991. Population stability of a tropical lizard. Ecology 72:1204-1217.

Blaustein, A. R., D. B. Wake, and W. P. Sousa. 1994. Amphibian declines: judging stability, persistence, and susceptibility of populations to local and global extinctions. Conservation Biology 8:60-71.

Blaustein, A. R., and J. M. Kiesecker. 2002. Complexity in conservation: lessons from the global decline of amphibian populations. Ecology Letters 5:597-608.

Carey, C., N. Cohen, and L. Rollins-Smith. 1999. Amphibian declines: an immunological perspective. Developmental and Comparative Immunology 23:459-472.

Clark, D. A., S. C. Piper, C. D. Keeling, and D. B. Clark. 2003. Tropical rain forest tree growth and atmospheric carbon dynamics linked to interannual temperature variation during 1984-2000. Proceedings of the National Academy of Sciences 100:5852-5857.

Coloma, L. A. 1995. Ecuadorian frogs of the genus Colostethus (Anura: Dendrobatidae). Miscellaneous publication 87. Museum of Natural History, University of Kansas, Lawrence, KS.

Donnelly, M. A. 1989. Reproductive phenology and age structure of Dendrobates pumilio in northeastern Costa Rica. Journal of Herpetology 23:362-367.

Donnelly, M. A. 1994. Amphibian diversity and natural history. In L. A. McDade, editor. La Selva: ecology and natural history of a neotropical rainforest. The University of Chicago Press, Chicago, IL.

Donnelly, M. A. 1999. Reproductive phenology of Eleutherodactylus bransfordii in northeastern Costa Rica. Journal of Herpetology 33:624-631.

Donnelly, M. A., and M. L. Crump. 1998. Potential effects of climate change on two neotropical amphibian assemblages. Climatic Change 39:541-561. 
Duellman, W. E. 1995. Temporal fluctuations in abundances of anuran amphibians in a seasonal Amazonian rainforest. Journal of Herpetology 29:13-21.

Fauth, J. E., B. I. Crother, and J. B. Slowinski. 1989. Elevational patterns of species richness, evenness, and abundance of the Costa Rican leaf-litter herpetofauna. Biotropica 21:178-185.

Frankie, G. W., H. G. Baker, and P. A. Opler. 1974. Comparative phonological studies of trees in tropical wet and dry forests in the lowlands of Costa Rica. The Journal of Ecology 62:881-919.

Gibbons, J. W., D. E. Scott, T. J. Ryan, K. A. Buhlmann, T. D. Tuberville, B. S. Metts, J. L. Greene, T. Mills, Y. Leiden, S. Poppy, and C. T. Winne. 2000. The global decline of reptiles, déjà vu amphibians. Bioscience 50:653-666.

Green, D. M. 2003. The ecology of extinction: population fluctuation and decline in amphibians. Biological Conservation 111:331-343.

Guyer, C. 1986. The role of food in regulating population density in a tropical mainland anole, Norops humilis. PhD. Dissertation, University of Miami, Coral Gables, FL.

Guyer, C. 1988. Food supplementation in a tropical mainland anole, Norops humilis: demographic effects. Ecology 69:350-361.

Guyer, C. 1990. The herpetofauna of La Selva, Costa Rica in Four neotropical rainforests, A. H. Gentry, ed. Yale University Press, New Haven, CT.

Guyer, C. 1994. The reptile fauna: diversity and ecology. In L. A. McDade, editor. La Selva: ecology and natural history of a neotropical rainforest. The University of Chicago Press, Chicago, IL.

Guyer, C., and M. A. Donnelly. 2005. Amphibians and reptiles of La Selva, Costa Rica, and the Caribbean slope. University of California Press. Berkeley, CA.

Heinen, J. T. 1992. Comparisons of the leaf litter herpetofauna in abandoned cacao plantations and primary rain forest in Costa Rica: some implications for faunal restoration. Biotropica 24:431-439.

Heyer, W. R., A. S. Rand, C. A. Goncalvez de Cruz, and O. L. Peixoto. 1988. Decimations, extinctions, and colonizations of frog populations in southeast Brazil and their evolutionary implications. Biotropica 20:230-235. 
Houlahan, J. E., C. S. Findlay, B. R. Schmidt, A. H. Meyer, and S. L. Kuzmin. 2000. Quantitative evidence for global amphibian population declines. Nature 404:752755 .

Inger. R. F., and H. K. Voris. 1993. A comparison of amphibian communities through time and from place to place in Bornean forests. Journal of Tropical Ecology 9:409-433.

Jaeger, R. G., and R. F. Inger. 1994. Quadrat sampling. In W. R. Heyer, M. A. Donnelly, R. W. McDiarmid, L. C. Hayek, and M. S. Foster, editors. Measuring and monitoring biological diversity: standard methods for amphibians. Smithsonian Institution Press, Washington, DC.

La Marca, E., and H. P. Reinthaler. 1991. Population changes in Atelopus species of the Cordillera de Mérida, Venezuela. Herpetological Review 22:125-128.

Laurance, W. F. 1996. Catastrophic declines of Australian rainforest frogs: is unusual weather responsible? Biological Conservation 77:203-212.

Lieberman, D., and M. Lieberman. 1987. Forest tree growth and dynamics at La Selva, Costa Rica (1969-1982). Journal of Tropical Ecology 3:347-358.

Lieberman, S. S. 1986. Ecology of the leaf litter herpetofauna of a neotropical rain forest: La Selva, Costa Rica. Acta Zoologica Mexicana 15:1-72.

Lieberman, S. S., and C. F. Dock. 1982. Analysis of the leaf litter arthropod fauna of a lowland tropical evergreen forest site (La Selva, Costa Rica). Revista Biologica Tropical 30:27-34.

Lips, K. R., J. R. Mendelson III, A. Muñoz-Alonso, L. Canseco-Márquez, and D. G. Mulcahy. 2004. Amphibian population declines in montane southern Mexico: resurveys of historical localities. Biological Conservation 119:555-564.

Lips, K. R., J. D. Reeve, and L. R. Witters. 2003. Ecological traits predicting amphibian population declines in Central America. Conservation Biology 17:1078-1088.

Manly, B. F. J. 1991. Randomization and Monte Carlo methods in biology. Chapman and Hall, London, UK.

Martinez-Solano, I., J. Bosch, and M. Garcia-Paris. 2003. Demographic trends and community stability in a montane amphibian assemblage. Conservation Biology 17:238-244. 
McDade, L. A., and G. S. Hartshorn. 1994. La Selva Biological Station. In L. A. McDade, editor. La Selva: ecology and natural history of a neotropical rainforest. The University of Chicago Press, Chicago, IL.

Meyer, A. H., B. R. Schmidt, and K. Grossenbacher. 1998. Analysis of three amphibian populations with quarter-century long time-series. Proceedings of the Royal Society of London B 265:523-528.

Pechmann, J. H. K., D. E. Scott, R. D. Semlitsch, J. P. Caldwell, L. J. Vitt, and J. W. Gibbons. 1991. Declining amphibian populations: the problem of separating human impacts from natural fluctuations. Science 253:892-895.

Pechmann, J. H. K., and H. M. Wilbur. 1994. Putting declining amphibian populations in perspective: natural fluctuations and human impacts. Herpetologica 50:65-84.

Pounds. J. A. 2000. Amphibians and reptiles in Monteverde: ecology and conservation of a tropical cloud forest. Oxford University Press, New York, NY.

Pounds, J. A., M. L. P. Fogden, and J. H. Campbell. 1999. Biological response to climate change on a tropical mountain. Nature 398:611-615.

Pounds, J. A., M. P. L. Fogden, J. M. Savage, and G. C. Gorman. 1997. Tests of null models for amphibian declines on a tropical mountain. Conservation Biology 7:1307-1322.

Rodriguez, L. O. 1992. Structure et organization du peuplement d'Anoures de Cocha Cashu, Parc National Manu, Amazonie Péruvienne. Revue d'Ecologie la Terre et la Vie 47:151-197.

Sanchez-Azofeifa, G. A., C. Quesada-Mateo, P. Gonzalez-Quesada, S. Dayanandan, and K. S. Bawa. 1999. Protected areas and conservation of biodiversity in the tropics. Conservation Biology 13:407-411.

Savage, J. M. 2002. The amphibians and reptiles of Costa Rica. The University of Chicago Press, Chicago, IL.

Schoener, T. W. 1985. Are lizard population sizes unusually constant through time? The American Naturalist 126:633-641.

Scott, N. J. 1976. The abundance and diversity of the herpetofaunas of tropical forest litter. Biotropica 8:41-58.

Scott, N. J. 1983. Eleutherodactylus bransfordii in Costa Rican natural history, D. H. Janzen, ed. University of Chicago Press, Chicago, IL. 
Skelly, D. K., K. L. Yurewicz, E. E. Werner, and R. A. Relyea. 2003. Estimating decline and distributional change in amphibians. Conservation Biology 17:744-751.

Toft, C. A. 1980. Seasonal variation in populations of Panamanian litter frogs and their prey: a comparison of wetter and drier sites. Oecologia 47:34-38.

Toft, C. A., A. S. Rand, and M. Clark. 1982. Population dynamics and seasonal recruitment in Bufo typhonius and Colostethus nubicola (Anura). In Leigh, E. G., A. S. Rand, and D. M. Windsor, eds. The ecology of a tropical forest. Smithsonian Institution Press, Washington, DC.

Vitt, L. J., and J. P. Caldwell. 1994. Resource utilization and guild structure of small vertebrates in the Amazon forest leaf-litter. Journal of Zoology 234:463-476.

Wake, D. B. 1991. Declining amphibian populations. Science 253:860.

Watling. J. I., and M. A. Donnelly. 2002. Seasonal patterns of reproduction and abundance of leaf litter frogs in a Central American rainforest. Journal of Zoology 258:269-276.

Watling, J. I., J. H. Waddle, D. Kizirian, and M. A. Donnelly. In press. Reproductive phenology of three lizard species in Costa Rica, with comments on seasonal reproduction of Neotropical lizards. Journal of Herpetology.

Whitfield, S. M., and M. S. F. Pierce. 2005. Tree buttress microhabitat use by a neotropical leaf-litter herpetofauna. Journal of Herpetology 39:192-198.

Woolbright, L. L. 1996. Disturbance influences long-term population patterns in the Puerto Rican frog, Eleutherodactylus coqui (Anura: Leptodactylidae). Biotropica 28:493-501.

Young, B. E., K. R. Lips, J. K. Reaser, R. Ibañez, A. W. Salas, J. R. Cedeño, L. A. Coloma, S. Ron, E. La Marca, J. R. Meyer, A. Muñoz, F. Bolaños, G. Chaves, and D. Romo. 2001. Population declines and priorities for amphibian conservation in Latin America. Conservation Biology 15:1213-1223. 


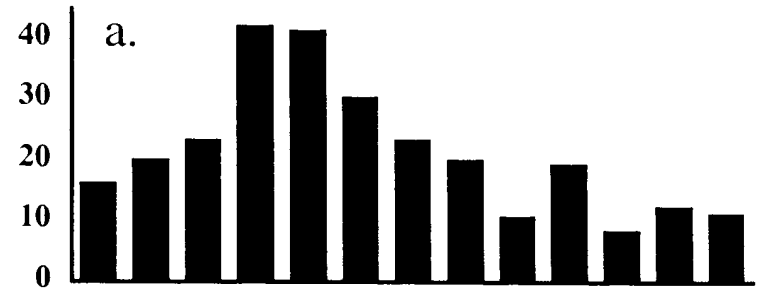

$\hat{n}^{3} \hat{n}^{x} \hat{n}^{x} \hat{n}^{x} \hat{n}^{x} \hat{n}^{x} \hat{n}^{x} \hat{n}^{x} \hat{n}^{x} \hat{n}^{x} \hat{n}^{x} \hat{n}^{x} \hat{n}^{x}$

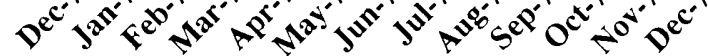
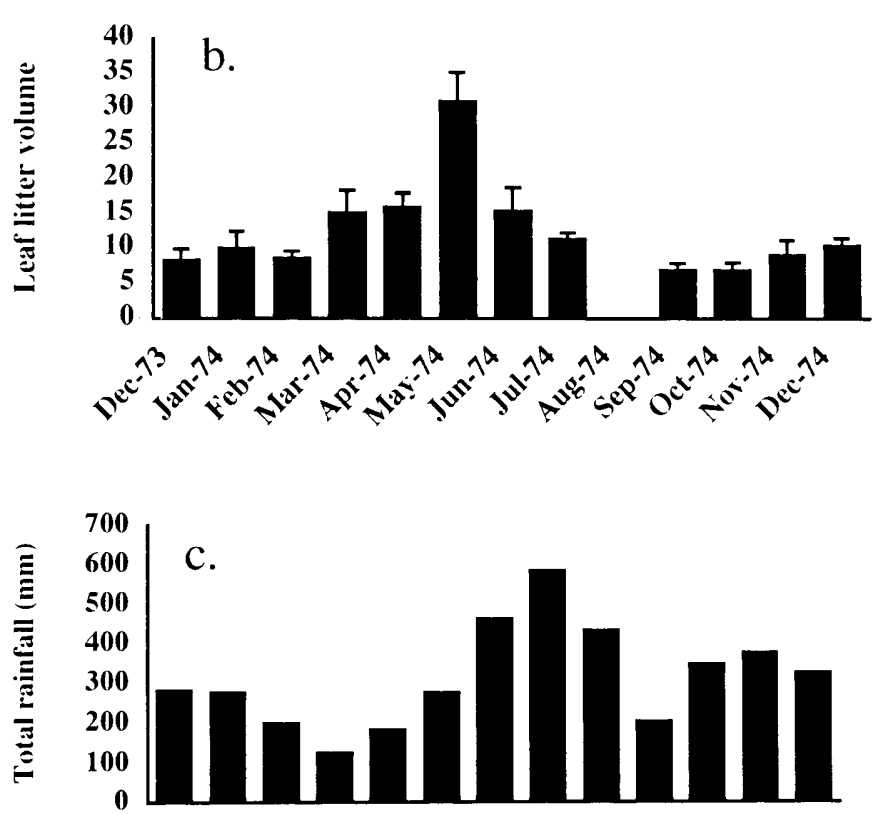

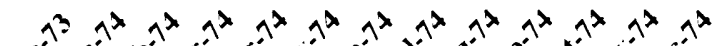

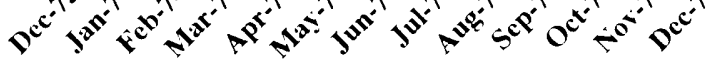
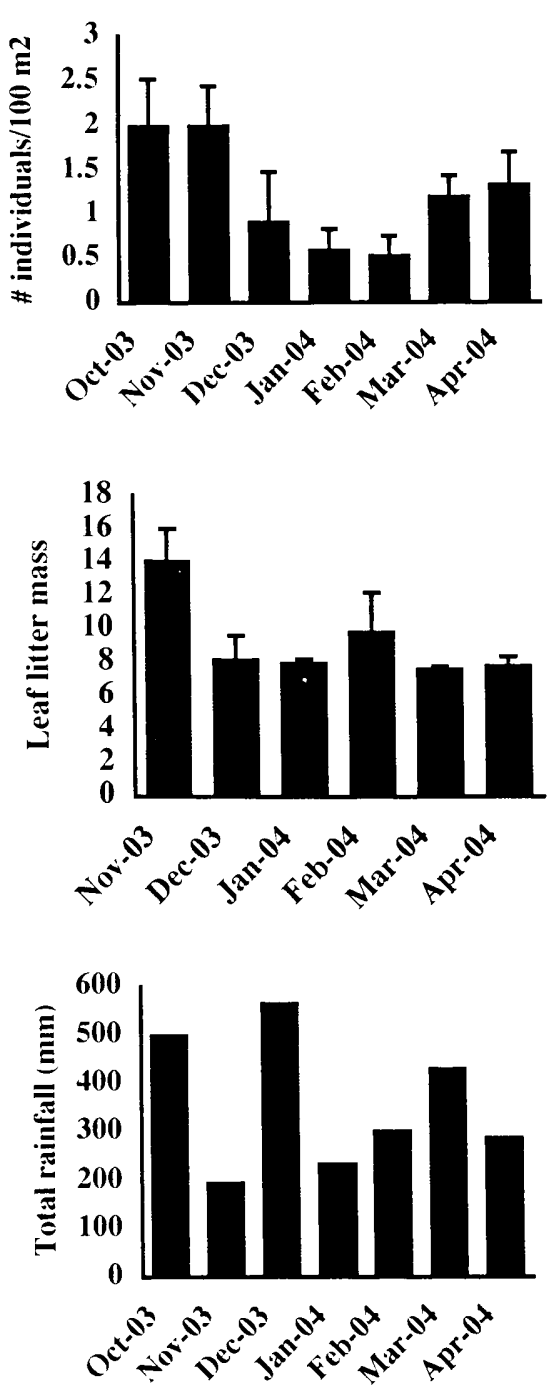

Figure 2.1. Reptile and amphibian density (a), leaf litter accumulation (b), and rainfall (c) for 1973-74 and 2003-04 at La Selva. Bars, when present, represent standard error (each mean in 1974 calculated from only 2 samples). 


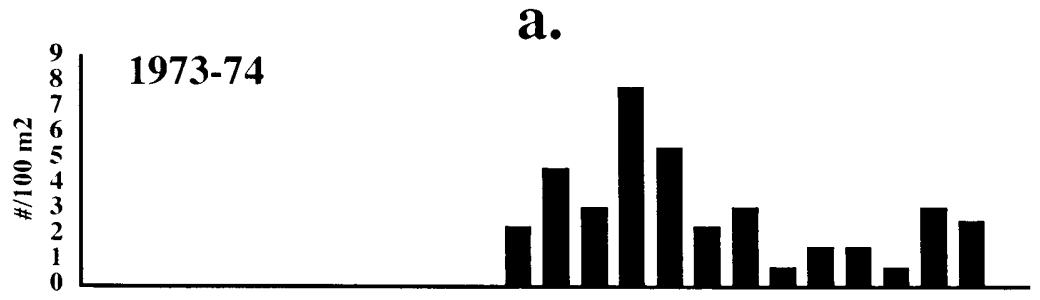

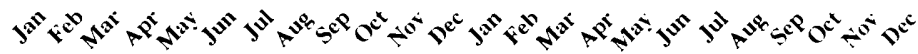
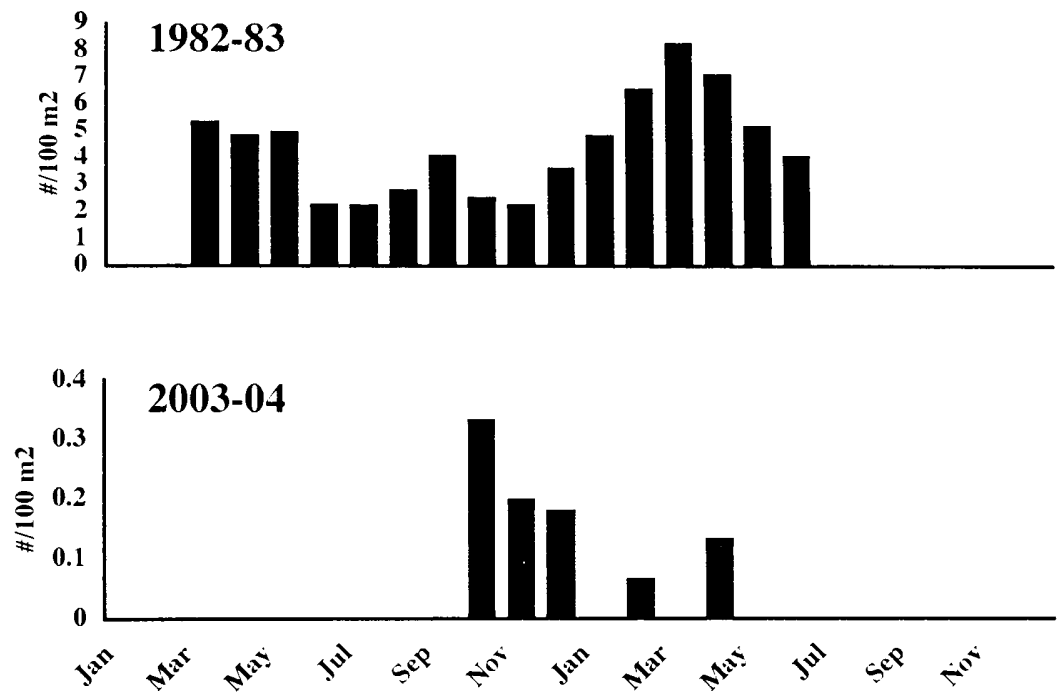

b.
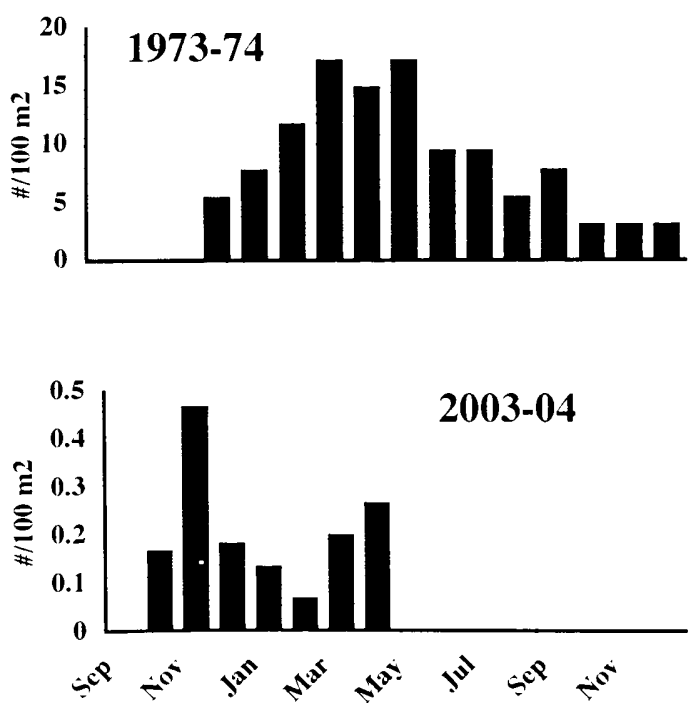

C.
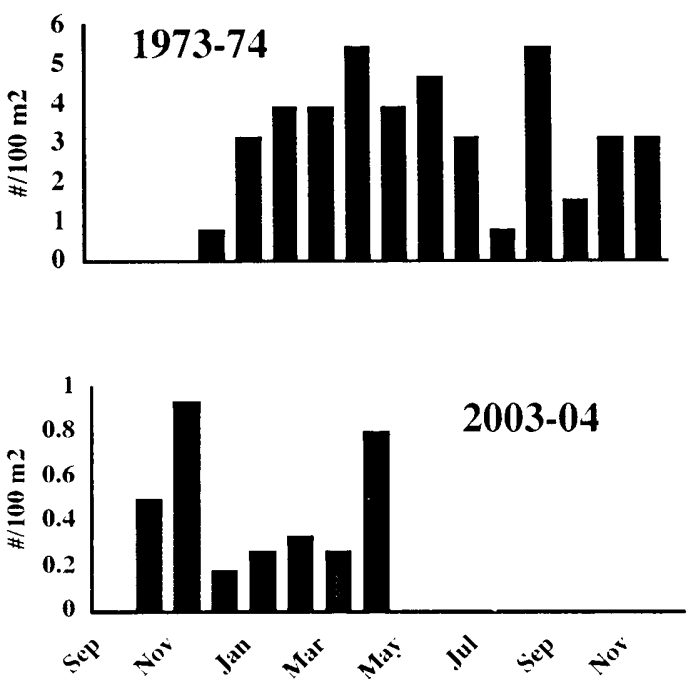

Figure 2.2. Seasonal patterns in density for Norops humilis (a), Eleutherodactylus bransfordii (b), and Dendrobates pumilio (c) in different years at La Selva, Costa Rica. 

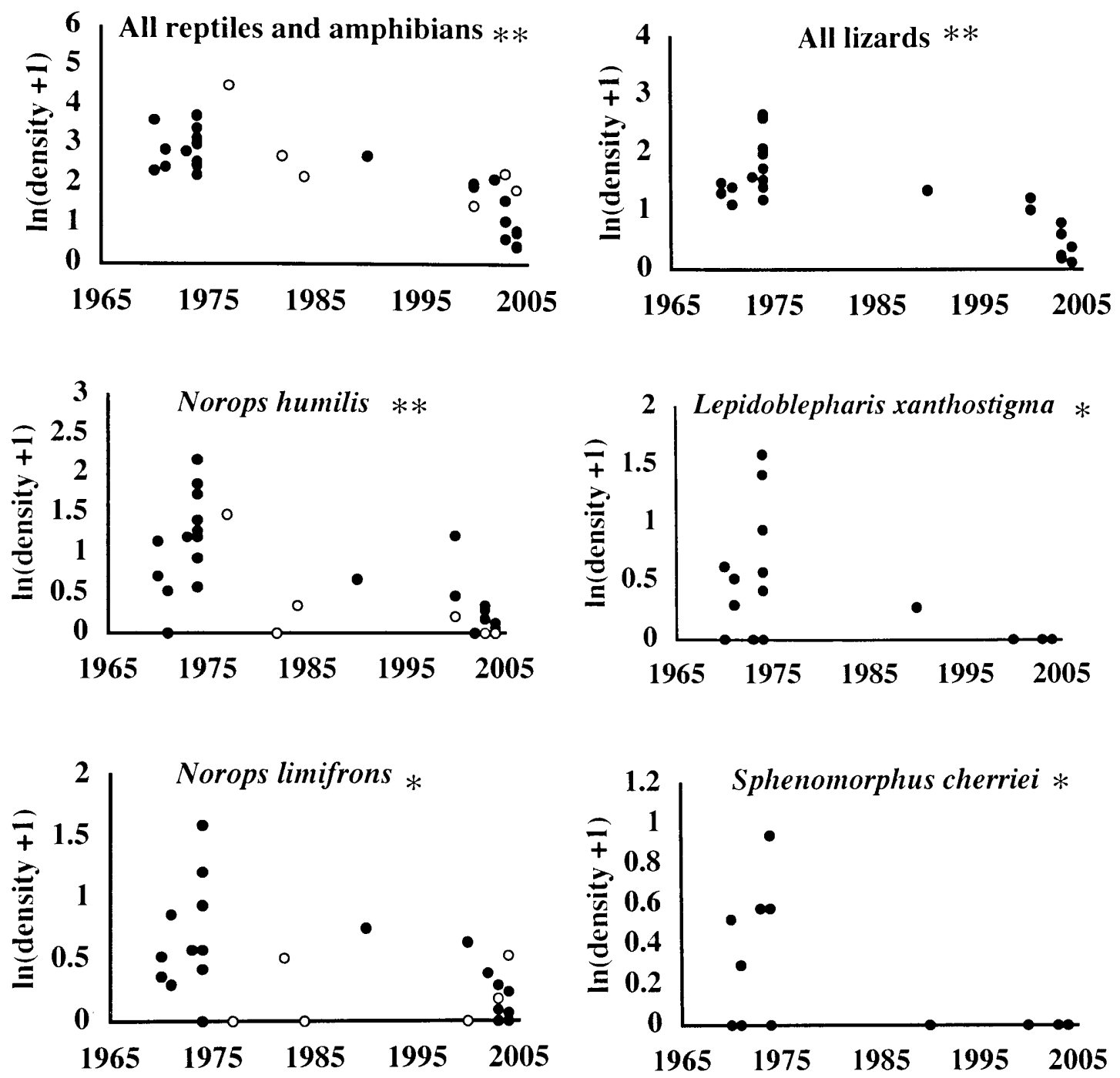

Figure 2.3. Changes in density of common species of reptiles and amphibian in primary forest at La Selva, Costa Rica, from 1970 to 2004. Each point represents a mean monthly density. Open circles indicate data taken from OTS course projects. $* P<0.05$; ${ }^{*} P<$ 0.01 (Kendall's tau). 

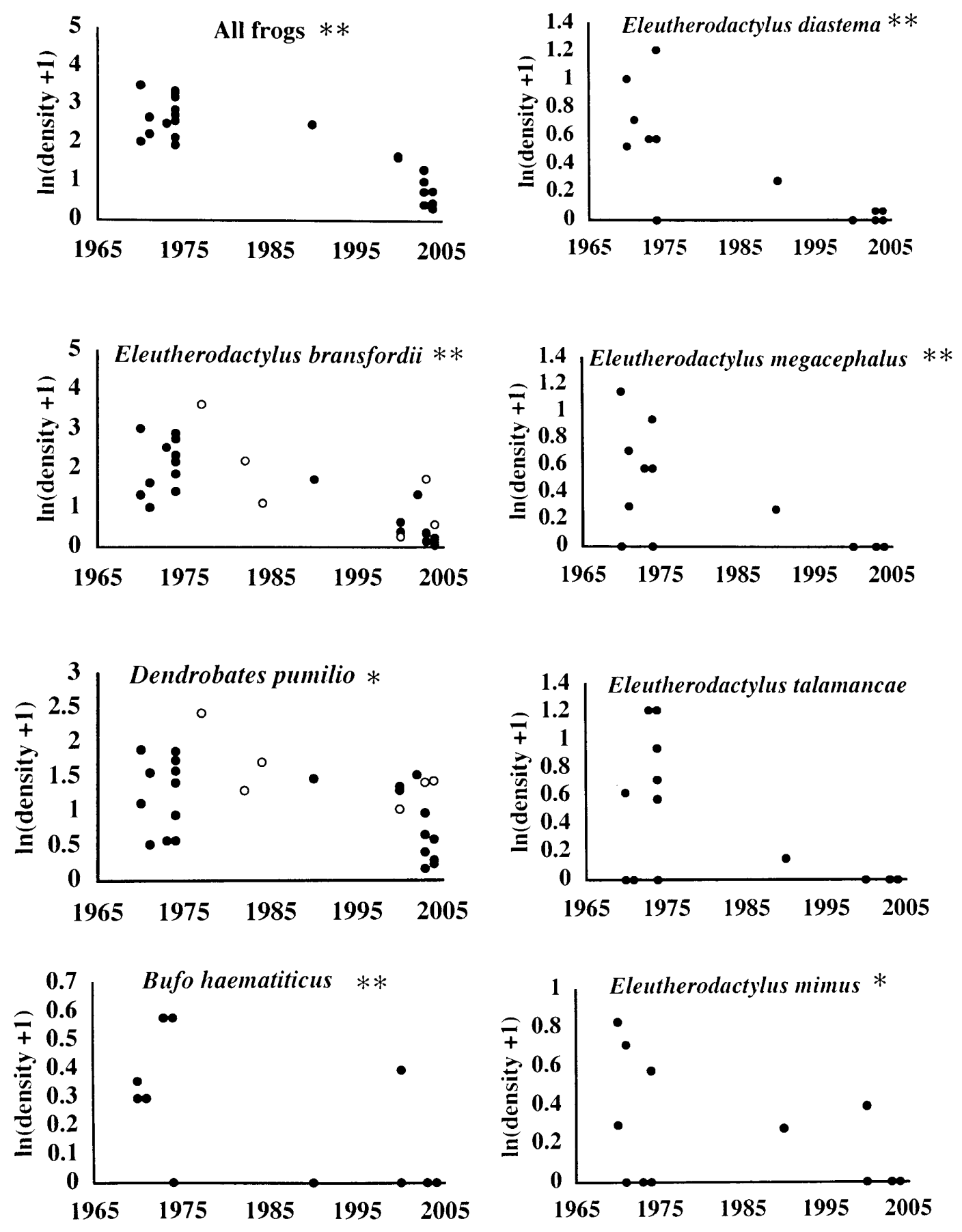

Figure 2.3. continued. 

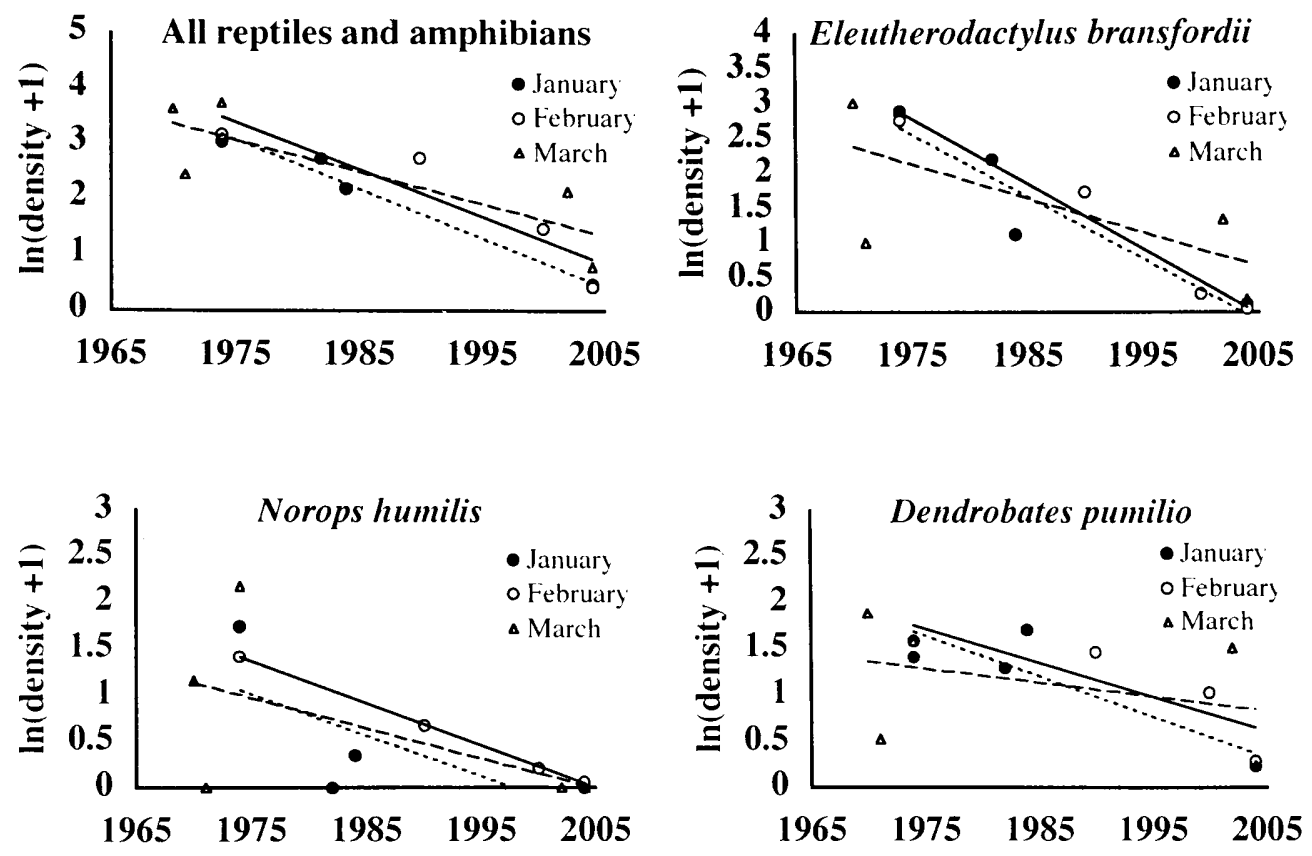

Figure 2.4. When only data from January, February, and March are plotted, negative trends are similar to those in the complete dataset. 

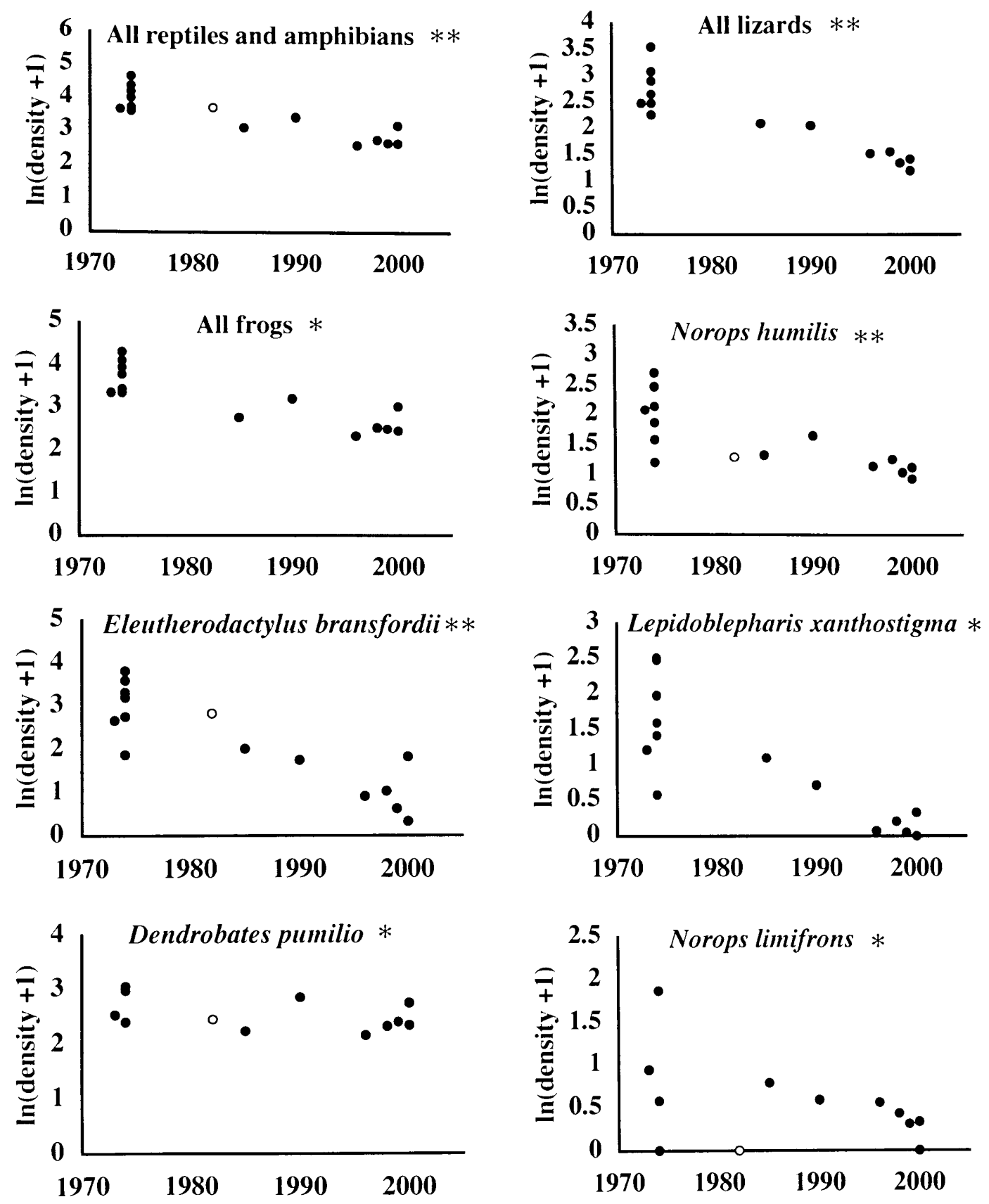

Figure 2.5. Changes in density of common species of reptiles and amphibians in abandoned cacao plantation at La Selva, Costa Rica, from 1973 to 2000. Each point represents a mean monthly density. Open circles indicate data taken from OTS course projects. ${ }^{*} \mathrm{P}<0.05 ; * * \mathrm{P}<0.01$ (Kendall's tau). 

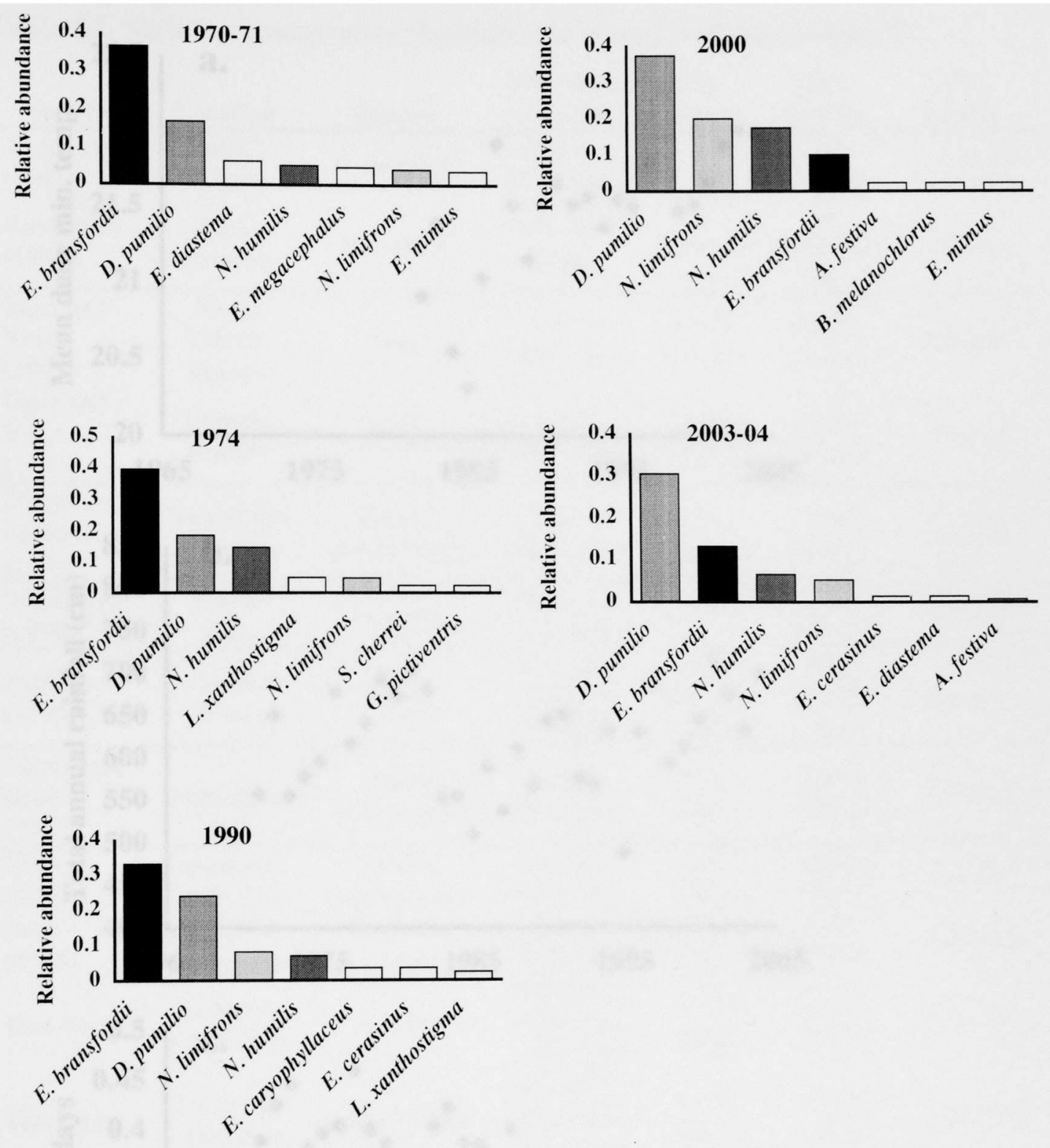

Figure 2.6. Relative abundance of species in primary forest at La Selva in different years (only 7 most abundant species found in each year shown). 

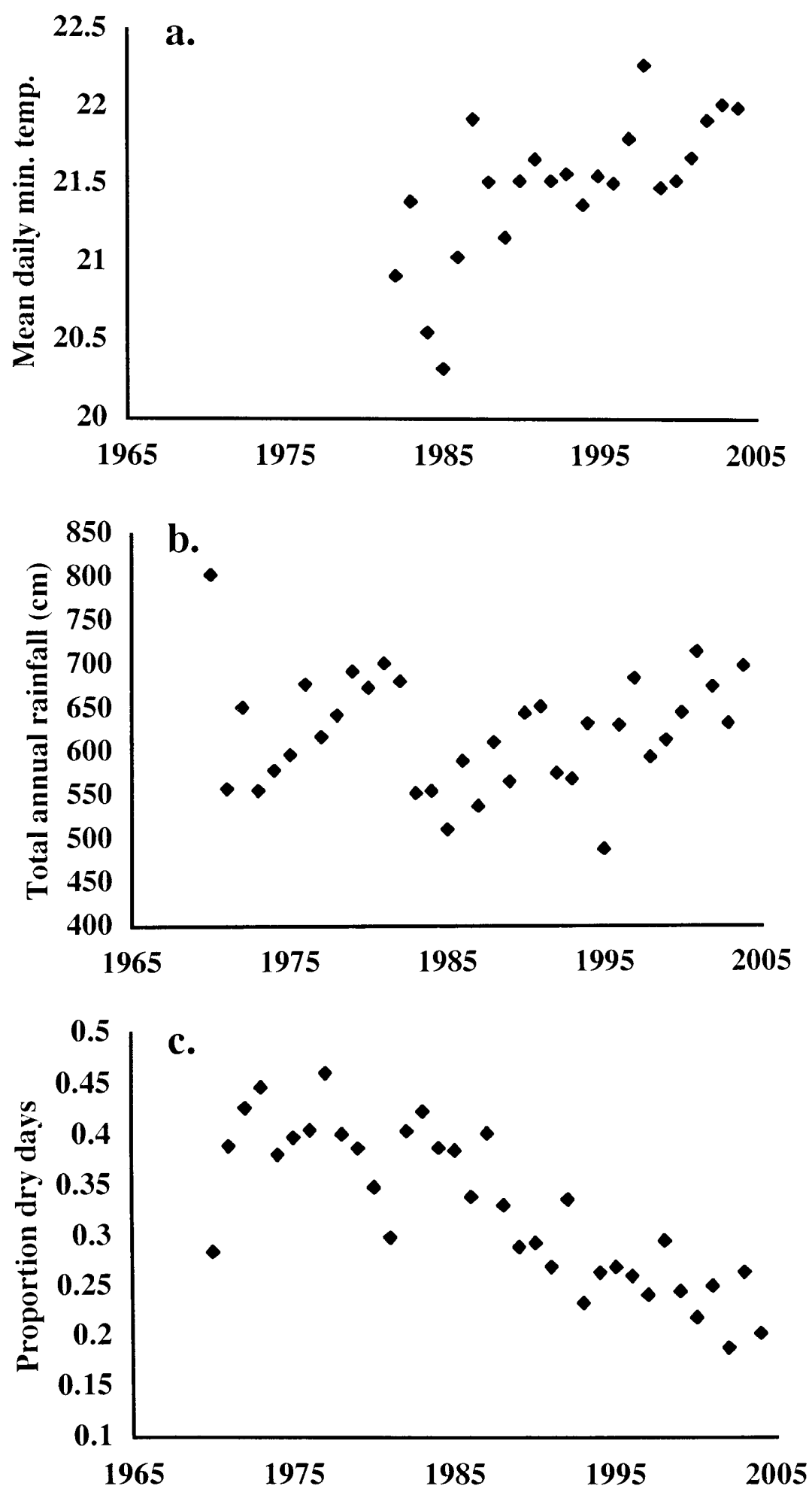

Figure 2.7. Annual mean of daily minimum temperature 1982-2004 (a), total annual rainfall 1970-2004 (b), and proportion of days with no rainfall 1970-2004 (c). 
Table 2.1. Variation among years in populations of tropical frogs and lizards.

\begin{tabular}{|c|c|c|c|c|c|c|}
\hline Source & Location & Species & $\begin{array}{l}\text { Sampling } \\
\text { frequency }\end{array}$ & $\begin{array}{l}\text { Min. } \\
\text { density }\end{array}$ & $\begin{array}{c}\text { Max. } \\
\text { density }\end{array}$ & $\begin{array}{c}\text { Max. } \\
\text { change }\end{array}$ \\
\hline $\begin{array}{l}\text { Andrews } \\
\text { (1991) }\end{array}$ & $\begin{array}{c}\text { BCI, } \\
\text { Panama }\end{array}$ & N. limifrons & $\begin{array}{c}\text { Yearly, } \\
1971-1989\end{array}$ & 0 & $\begin{array}{c}17.4 / \\
100 \mathrm{~m}^{2}\end{array}$ & $>17$-fold \\
\hline $\begin{array}{l}\text { Rand et al. } \\
\text { (1983) }\end{array}$ & $\begin{array}{c}\text { BCI, } \\
\text { Panama }\end{array}$ & H. rufitela & $\begin{array}{c}1931.1964 \\
1980\end{array}$ & $\begin{array}{c}1 \\
\text { breeding } \\
\text { site } \\
\end{array}$ & $\begin{array}{c}22 \\
\text { breeding } \\
\text { sites }\end{array}$ & 22-fold \\
\hline $\begin{array}{l}\text { Inger and } \\
\text { Voris } \\
\text { (1993) }\end{array}$ & $\begin{array}{l}\text { Nanga } \\
\text { Tekalit, } \\
\text { Borneo }\end{array}$ & Frogs & $\begin{array}{c}1962 \\
1970.1984\end{array}$ & $\begin{array}{c}23.68 / \\
\text { transect }\end{array}$ & $\begin{array}{l}58.53 / \\
\text { transect }\end{array}$ & 2.5 -fold \\
\hline $\begin{array}{l}\text { Inger and } \\
\text { Voris } \\
\text { (1993) }\end{array}$ & $\begin{array}{l}\text { Danum, } \\
\text { Borneo }\end{array}$ & Frogs & $\begin{array}{c}1986 \\
1989.1990\end{array}$ & $\begin{array}{c}76.56 / \\
\text { transect }\end{array}$ & $\begin{array}{c}19.88 / \\
\text { transect }\end{array}$ & 3.9-fold \\
\hline $\begin{array}{l}\text { Alford and } \\
\text { Richards } \\
\text { (1999) }\end{array}$ & $\begin{array}{c}\text { Queensland } \\
\text { Australia }\end{array}$ & $\begin{array}{c}\text { Litoria } \\
\text { genimaculata }\end{array}$ & $\begin{array}{c}\text { Yearly, } \\
1989-1995\end{array}$ & $\begin{array}{c}4 / \\
\text { transect }\end{array}$ & $\begin{array}{c}13.5 / \\
\text { transect }\end{array}$ & 3.4-fold \\
\hline $\begin{array}{l}\text { Woolbright } \\
\text { (1996) }\end{array}$ & $\begin{array}{c}\text { Puerto } \\
\text { Rico }\end{array}$ & E. coqui & $\begin{array}{l}\text { Bi-yearly, } \\
1987-1995 \\
\end{array}$ & $\begin{array}{c}6.25 / \\
100 \mathrm{~m}^{2} \\
\end{array}$ & $\begin{array}{l}23.13 / \\
100 \mathrm{~m}^{2}\end{array}$ & 3.7-fold \\
\hline $\begin{array}{l}\text { Duellman } \\
\text { (1995) }\end{array}$ & $\begin{array}{l}\text { Lowland } \\
\text { Peru }\end{array}$ & frogs & $\begin{array}{l}11-12 / 86 \\
11-12 / 89 \\
11-12 / 91\end{array}$ & $\begin{array}{c}4.58 / \\
\text { person- } \\
\text { day }\end{array}$ & $\begin{array}{c}17.21 \\
\text { person- } \\
\text { day } \\
\end{array}$ & 3.8-fold \\
\hline $\begin{array}{l}\text { Alcala and } \\
\text { Brown } \\
(1967)\end{array}$ & Phillipines & $\begin{array}{c}\text { Emoia } \\
\text { atrocostata }\end{array}$ & $\begin{array}{c}\text { Yearly, } \\
1962-1965\end{array}$ & $\begin{array}{c}0.3 / \\
100 \mathrm{~m}^{2}\end{array}$ & $\begin{array}{c}0.85 / \\
100 \mathrm{~m}^{2}\end{array}$ & 2.9-fold \\
\hline $\begin{array}{l}\text { Hirth } \\
(1963)\end{array}$ & $\begin{array}{l}\text { Tortuguero } \\
\text { Costa Rica }\end{array}$ & $\begin{array}{c}\text { Ameiva } \\
\text { quadrilineata }\end{array}$ & $\begin{array}{c}\text { Yearly, } \\
1959-1961\end{array}$ & $\begin{array}{c}0.36 / \\
100 \mathrm{~m}^{2}\end{array}$ & $\begin{array}{c}0.49 / \\
100 \mathrm{~m}^{2}\end{array}$ & 1.4-fold \\
\hline $\begin{array}{l}\text { Hirth } \\
\text { (1963) }\end{array}$ & $\begin{array}{l}\text { Tortuguero } \\
\text { Costa Rica }\end{array}$ & $\begin{array}{c}\text { Basiliscus } \\
\text { vittatus }\end{array}$ & $\begin{array}{c}\text { Yearly. } \\
1959-1961\end{array}$ & $\begin{array}{c}0.29 / \\
100 \mathrm{~m}^{2}\end{array}$ & $\begin{array}{c}0.32 / \\
100 \mathrm{~m}^{2}\end{array}$ & 1.1-fold \\
\hline This study & $\begin{array}{l}\text { La Selva, } \\
\text { Costa Rica }\end{array}$ & Litter frogs & $\begin{array}{l}1970,1971, \\
1974,1990, \\
2000.2004\end{array}$ & $\begin{array}{c}1.12 / \\
100 \mathrm{~m}^{2}\end{array}$ & $\begin{array}{l}20.04 / \\
100 \mathrm{~m}^{2}\end{array}$ & 17.9-fold \\
\hline This study & $\begin{array}{l}\text { La Selva, } \\
\text { Costa Rica }\end{array}$ & Litter lizards & $\begin{array}{l}1970,1971 \\
1974,1990 \\
2000.2004\end{array}$ & $\begin{array}{c}0.42 / \\
100 \mathrm{~m}^{2}\end{array}$ & $\begin{array}{c}5.99 / \\
100 \mathrm{~m}^{2}\end{array}$ & 14.3-fold \\
\hline
\end{tabular}


Table 2.2. Seasonal variation in populations of tropical frogs and lizards.

\begin{tabular}{|c|c|c|c|c|c|c|}
\hline Source & Location & Species & $\begin{array}{l}\text { Sampling } \\
\text { frequency }\end{array}$ & $\begin{array}{c}\text { Max. } \\
\text { density }\end{array}$ & $\begin{array}{l}\text { Min. } \\
\text { density }\end{array}$ & $\begin{array}{c}\text { Max. } \\
\text { change }\end{array}$ \\
\hline $\begin{array}{l}\text { Allmon } \\
(1991)\end{array}$ & $\begin{array}{c}\text { Central } \\
\text { Amazonia }\end{array}$ & Litter frogs & $\begin{array}{l}\text { Monthly, } \\
3 / 84-6 / 85\end{array}$ & $\begin{array}{c}13.68 / \\
100 \mathrm{~m}^{2}\end{array}$ & $\begin{array}{c}1.8 / \\
100 \mathrm{~m}^{2}\end{array}$ & 7.6-fold \\
\hline $\begin{array}{l}\text { Rodriguez } \\
\text { (1992) }\end{array}$ & $\begin{array}{l}\text { Floodplain } \\
\text { Forest, } \\
\text { Manu NP, } \\
\text { Peru }\end{array}$ & Litter frogs & $\begin{array}{c}\text { Wet/dry } \\
\text { season. } 1988\end{array}$ & $\begin{array}{c}4.17 / \\
100 \mathrm{~m}^{2}\end{array}$ & $\begin{array}{c}1.2 / 100 \\
\mathrm{~m}^{2}\end{array}$ & 3.5 -fold \\
\hline $\begin{array}{l}\text { Rodriguez } \\
\text { (1992) }\end{array}$ & $\begin{array}{c}\text { Terra } \\
\text { Firme. } \\
\text { Manu NP, } \\
\text { Peru }\end{array}$ & Litter frogs & $\begin{array}{c}\text { Wet/dry } \\
\text { season, } 1988\end{array}$ & $\begin{array}{c}3 / \quad 100 \\
\mathrm{~m}^{2}\end{array}$ & $1 / 1 /$ & 3 -fold \\
\hline $\begin{array}{l}\text { Duellman } \\
\text { (1995) }\end{array}$ & $\begin{array}{l}\text { Lowland } \\
\text { Peru }\end{array}$ & frogs & $\begin{array}{c}1-2 / 86.11- \\
12 / 86,6-7 / 89 \\
11-12 / 89\end{array}$ & $\begin{array}{c}17.21 \\
\text { person- } \\
\text { day }\end{array}$ & $\begin{array}{c}3.88 / \\
\text { person- } \\
\text { day }\end{array}$ & 4.4-fold \\
\hline $\begin{array}{l}\text { Stewart } \\
\text { (1995) }\end{array}$ & $\begin{array}{c}\text { Puerto } \\
\text { Rico }\end{array}$ & E. coqui & $\begin{array}{c}\text { Monthly, } \\
\text { 1/80-12/80 }\end{array}$ & $\begin{array}{c}200 / \\
100 \mathrm{~m}^{2}\end{array}$ & $\begin{array}{c}46 / \\
100 \mathrm{~m}^{2}\end{array}$ & 4-fold \\
\hline $\begin{array}{l}\text { Toft } \\
(1980)\end{array}$ & Panama & Litter frogs & $\begin{array}{l}\text { Wet/dry } \\
\text { season }\end{array}$ & $\begin{array}{c}22.5 / \\
100 \mathrm{~m}^{2}\end{array}$ & $\begin{array}{c}7.5 / \\
100 \mathrm{~m}^{2}\end{array}$ & 3 -fold \\
\hline $\begin{array}{c}\text { Toft et al. } \\
\text { (1982) }\end{array}$ & $\begin{array}{c}\text { BCI, } \\
\text { Panama }\end{array}$ & C. nubicola & $\begin{array}{l}\text { Monthly. } \\
\text { 11/76-12/78 }\end{array}$ & $\begin{array}{c}115 \\
\text { (count) }\end{array}$ & 0 & $>115$-fold \\
\hline $\begin{array}{c}\text { Toft et al. } \\
\text { (1982) }\end{array}$ & $\begin{array}{c}\text { BCI, } \\
\text { Panama }\end{array}$ & B.typhonius & $\begin{array}{l}\text { Monthly, } \\
11 / 76-12 / 78\end{array}$ & $\begin{array}{c}38 \\
\text { (count) }\end{array}$ & 0 & $>38$-fold \\
\hline $\begin{array}{l}\text { Guyer } \\
\text { ( 1988) }\end{array}$ & $\begin{array}{l}\text { LS, Costa } \\
\text { Rica }\end{array}$ & N. humilis & $\begin{array}{l}\text { Monthly, } \\
3 / 82-6 / 83\end{array}$ & $\begin{array}{c}8.3 / \\
100 \mathrm{~m}^{2}\end{array}$ & $\begin{array}{c}2.22 / \\
100 \mathrm{~m}^{2}\end{array}$ & 3.7-fold \\
\hline 1974 data & $\begin{array}{l}\text { LS, Costa } \\
\text { Rica }\end{array}$ & Litter frogs & $\begin{array}{l}\text { Monthly. } \\
12 / 73-12 / 74\end{array}$ & $\begin{array}{c}28.9 / \\
100 \mathrm{~m}^{2}\end{array}$ & $\begin{array}{c}6.25 / \\
100 \mathrm{~m}^{2}\end{array}$ & 4.6-fold \\
\hline 1974 data & $\begin{array}{l}\text { LS, Costa } \\
\text { Rica }\end{array}$ & $\begin{array}{c}E . \\
\text { bransfordii }\end{array}$ & $\begin{array}{l}\text { Monthly, } \\
12 / 73-12 / 74\end{array}$ & $\begin{array}{c}17.19 / \\
100 \mathrm{~m}^{2}\end{array}$ & $\begin{array}{c}3.13 / \\
100 \mathrm{~m}^{2}\end{array}$ & 5.5 -fold \\
\hline 1974 data & $\begin{array}{l}\text { LS, Costa } \\
\text { Rica }\end{array}$ & Litter lizards & $\begin{array}{l}\text { Monthly, } \\
12 / 73-12 / 74\end{array}$ & $\begin{array}{l}13.28 / \\
100 \mathrm{~m}^{2}\end{array}$ & $\begin{array}{c}2.34 / \\
100 \mathrm{~m}^{2}\end{array}$ & 5.7-fold \\
\hline 2004 data & $\begin{array}{l}\text { LS, Costa } \\
\text { Rica }\end{array}$ & Litter frogs & $\begin{array}{l}\text { Monthly, } \\
\text { 10/03-4/04 }\end{array}$ & $\begin{array}{c}1.8 / \\
100 \mathrm{~m}^{2}\end{array}$ & $\begin{array}{c}0.4 / 100 \\
\mathrm{~m}^{2}\end{array}$ & 4.5 -fold \\
\hline 2004 data & $\begin{array}{l}\text { LS, Costa } \\
\text { Rica }\end{array}$ & $\begin{array}{c}E . \\
\text { bransfordii }\end{array}$ & $\begin{array}{l}\text { Monthly, } \\
\text { 10/03-4/04 }\end{array}$ & $\begin{array}{c}0.47 / \\
100 \mathrm{~m}^{2}\end{array}$ & $\begin{array}{c}0.07 / \\
100 \mathrm{~m}^{2}\end{array}$ & 6.7-fold \\
\hline 2004 data & $\begin{array}{l}\text { LS. Costa } \\
\text { Rica }\end{array}$ & Litter lizards & $\begin{array}{l}\text { Monthly, } \\
\text { 10/03-4/04 }\end{array}$ & $\begin{array}{c}0.83 / \\
100 \mathrm{~m}^{2}\end{array}$ & $\begin{array}{c}0.13 / \\
100 \mathrm{~m}^{2}\end{array}$ & 6.4-fold \\
\hline
\end{tabular}


Table 2.3. Sources of data used in analysis. Sources in gray indicate data from OTS course projects.

Primary Forest, Daytime Leaf-litter Plot Sampling

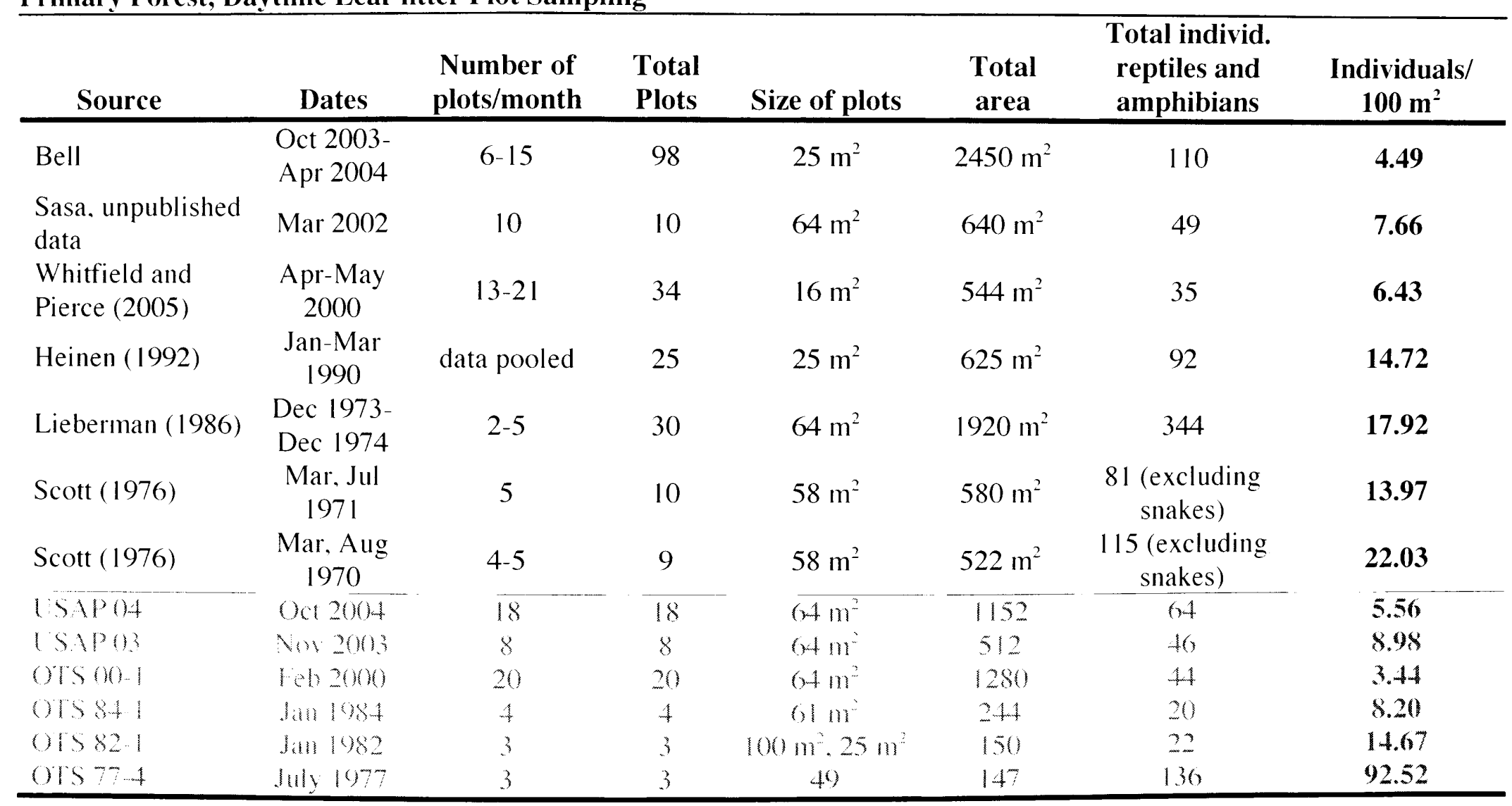


Abandoned Cacao Plantation, Daytime Leaf-litter Plot Sampling

\begin{tabular}{|c|c|c|c|c|c|c|c|}
\hline Source & Dates & $\begin{array}{l}\text { Number of } \\
\text { plots/month }\end{array}$ & $\begin{array}{l}\text { Total } \\
\text { Plots }\end{array}$ & Size of plots & $\begin{array}{l}\text { Total } \\
\text { area }\end{array}$ & $\begin{array}{l}\text { Total individ. } \\
\text { reptiles and } \\
\text { amphibians }\end{array}$ & $\begin{array}{c}\text { Individuals/ } \\
100 \mathrm{~m}^{2}\end{array}$ \\
\hline $\begin{array}{l}\text { Whitfield and } \\
\text { Pierce (2005) }\end{array}$ & $\begin{array}{l}\text { Apr-May } \\
2000\end{array}$ & $6-16$ & 22 & $16 \mathrm{~m}^{2}$ & $352 \mathrm{~m}^{2}$ & 58 & 16.48 \\
\hline $\begin{array}{l}\text { Donnelly, } \\
\text { unpublished data }\end{array}$ & May 1999 & 40 & 40 & $144 \mathrm{~m}^{2}$ & $5760 \mathrm{~m}^{2}$ & 802 & 13.92 \\
\hline $\begin{array}{l}\text { Donnelly, } \\
\text { unpublished data }\end{array}$ & Mar 1998 & 40 & 40 & $144 \mathrm{~m}^{2}$ & $5760 \mathrm{~m}^{2}$ & 884 & 15.35 \\
\hline $\begin{array}{l}\text { Donnelly, } \\
\text { unpublished data }\end{array}$ & Sep 1996 & 40 & 40 & $144 \mathrm{~m}^{2}$ & $5760 \mathrm{~m}^{2}$ & 741 & 12.86 \\
\hline Heinen (1992) & $\begin{array}{c}\text { Jan-Mar } \\
1990\end{array}$ & data pooled & 50 & $25 \mathrm{~m}^{2}$ & $1250 \mathrm{~m}^{2}$ & 386 & 30.88 \\
\hline $\begin{array}{l}\text { Fauth et al. } \\
\text { (1989) }\end{array}$ & Sep 1985 & 10 & 10 & $25 \mathrm{~m}^{2}$ & $250 \mathrm{~m}^{2}$ & 56 & 22.4 \\
\hline Lieberman (1986) & $\begin{array}{l}\text { Dec 1973- } \\
\text { Dec } 1974\end{array}$ & $1-6$ & 21 & $64 \mathrm{~m}^{2}$ & $1344 \mathrm{~m}^{2}$ & 660 & 49.10 \\
\hline OTS 82.1 & Ian 1982 & 3 & 3 & $25 \mathrm{~m}^{2}$ & $75 \mathrm{~m}^{2}$ & 31 & 41.33 \\
\hline
\end{tabular}


Table 2.4. Maximum seasonal change in abundance for common species in two years.

\begin{tabular}{lcc}
\hline & $\mathbf{1 9 7 3 - 7 4}$ (13 months) & $\mathbf{2 0 0 3 - 0 4}(6$ months) \\
\hline All frogs & 4.6 -fold & 4.5 -fold \\
All lizards & 5.7 -fold & 6.4 -fold \\
E. bransfordii & 5.5 -fold & 6.7 -fold \\
D. pumilio & 7 -fold & 5.2 -fold \\
$N$. humilis & 10 -fold & 4.7 -fold \\
$N$. limifrons & 7.5 -fold & 4.7 -fold \\
E. megacephalus & 2 -fold & \\
L.xanthostigma & 7.5 -fold & \\
S. cherriei & 2 -fold & \\
\hline
\end{tabular}

Table 2.5. Changes in density over 35 years in forest and cacao at La Selva, Costa Rica.

\begin{tabular}{lcccccc}
\hline & & & \multicolumn{2}{c}{ Forest (excluding } & \multicolumn{2}{c}{ Cacao } \\
& \multicolumn{1}{c}{ Forest (all datasets) } & \multicolumn{2}{c}{ OTS course data) } & $\boldsymbol{\tau}$ & $\boldsymbol{\boldsymbol { \tau }}$ \\
\hline All reptiles and & -0.59 & $<0.001$ & -0.55 & $<0.001$ & -0.61 & 0.002 \\
amphibians & & & & & & \\
All frogs & & & -0.57 & $<0.001$ & -0.59 & 0.012 \\
All lizards & & & -0.51 & $<0.001$ & -0.69 & 0.003 \\
E. bransfordii & -0.54 & $<0.001$ & -0.58 & $<0.001$ & -0.63 & 0.002 \\
D. pumilio & -0.34 & 0.008 & -0.30 & 0.038 & -0.41 & 0.045 \\
N. humilis & -0.48 & $<0.001$ & -0.44 & 0.003 & -0.65 & 0.001 \\
N. limifrons & -0.28 & 0.030 & -0.34 & 0.023 & -0.45 & 0.029 \\
E. diastema & & & -0.42 & 0.009 & -0.02 & 0.94 \\
E. megacephalus & & & -0.50 & 0.002 & -0.22 & 0.39 \\
L. xanthostigma & & & -0.37 & 0.018 & -0.60 & 0.010 \\
S. cherriei & & & -0.38 & 0.020 & -0.21 & 0.37 \\
E. mimus & & & -0.37 & 0.025 & & \\
B. haematiticus & & & -0.50 & 0.002 & & \\
G. pictiventris & & & -0.09 & 0.58 & & \\
E. talamancae & & & -0.31 & 0.063 & & \\
\hline
\end{tabular}




\section{CONCLUSIONS}

The small forest fragments studied here each contained 20 to $50 \%$ of the frogs and lizard species I found in the region, a greater number of species than might be expected based on the small sizes and high levels of disturbance of the study sites. The relatively high diversity I observed in these sites makes them relevant in terms of reptile and amphibian conservation, although fragments may still be losing species decades after isolation. Taken together, the nine fragments contained $82 \%$ of the species richness I encountered in continuous forest (or $58 \%$ of the regional total). Thus, preserving a network of small forest patches may be of great conservation value to herpetofauna in the Sarapiquí region and at other lowland sites.

Although a significant proportion of the herpetofauna may be able to exist in small forest patches, it should be recognized that the communities in these fragments are fundamentally different from the intact forest community. Nine of the 36 species (25\%) I found in continuous forest were missing from fragments. Species composition and relative abundances differ, and fragments tend to support higher densities of lizards and lower densities of frogs than continuous forest. Therefore, the continued presence of La Selva and other large reserves is vital to the preservation of reptiles and amphibians in the fragmented Sarapiquí region.

But how "intact" is the forest within La Selva? Although the overall density of herpetofauna does not differ between fragments and La Selva, the density observed at La Selva in 2004 is the lowest recorded in 35 years. The compiled data either indicate faunal declines at La Selva or population fluctuations greater than those found in other 
tropical assemblages. Simultaneous negative trends in the density of leaf litter frogs and lizards at La Selva resemble the declines across unrelated taxa at Monteverde..

This system seems to exemplify the "sliding baseline" problem of evaluating anthropogenic impacts while in the midst of a climatic or other major regime shift (Dayton et al. 1998). While forest fragments in my study maintained herpetofaunal densities comparable to those in La Selva in 2004, La Selva's "baseline" has shifted dramatically since the early 1970s, when densities were ten times higher. The abrupt downward trend of amphibians and reptile populations across the decades at La Selva should make us aware that the site has changed greatly over the past decades and may no longer represent intact lowland tropical forest. As one of only a few large areas of Caribbean lowland forest remaining in Costa Rica, La Selva appears to be vulnerable to surrounding land use change, climate change, or some other combination of factors. Its value to the conservation of reptiles and amphibians is dependent on our gaining a better understanding of the factors influencing long-term population changes.

Dayton, P. K., M. J. Tegner, P. B. Edwards, and K. L. Riser. 1998. Sliding baselines, ghosts, and reduced expectations in kelp forest communities. Ecological Applications 8:309-322. 